$$
\begin{aligned}
& \text { دور أنماط القيادة الاتوقراطية في تعزيز مستوى التماثل التنيمي } \\
& \text { " دراسة استطلاعية لاراء عينة من موظفي مديرية تربية زاخو " } \\
& \text { علي عبداللطيف عبدالله و روش ابراهيم محمد و محمد عبدالرممن عمر }
\end{aligned}
$$

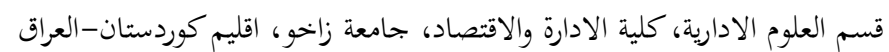

$$
\begin{aligned}
& \text { (تاريخ استلام البحث: } 25 \text { ايلول، 2018، تاريخ القبول بالنشر: } 30 \text { نيسان، 2019) }
\end{aligned}
$$

الخلاصة

يهدف البحث الى تحديد دور انماط القيادة الاوتوقراطية في التماثل التنظيمي لدى موظفي مديرية تربية زاخو. وقدم البحث اطاراً نظرياً تناول

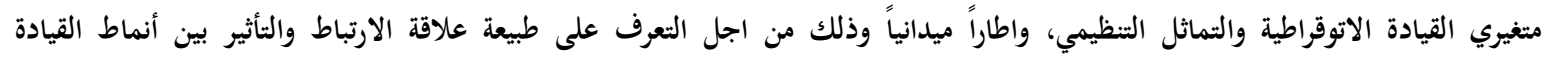

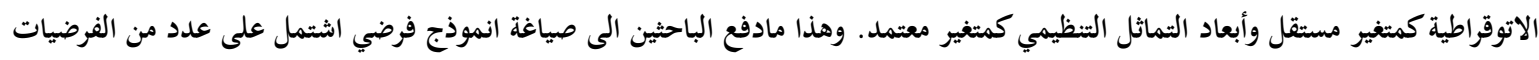

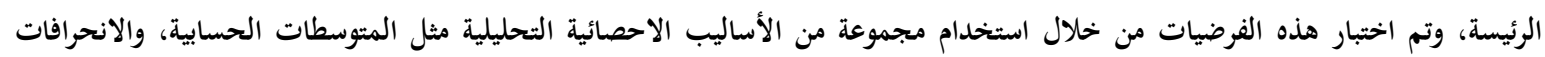

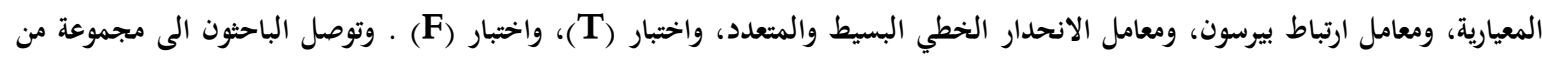

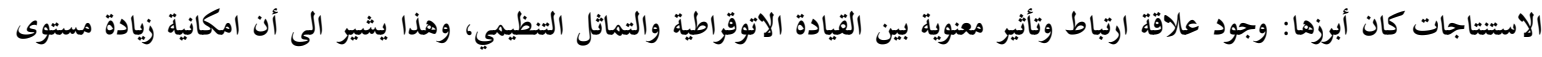

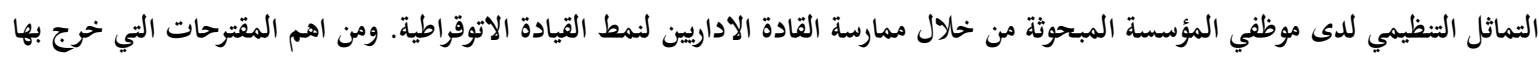

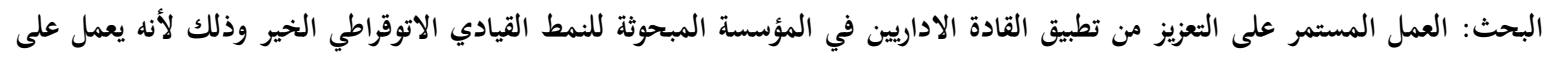
تنمية ولاء الافراد التابعين وشعورهم بالانتماء لمنظمتهم مما سينعكس اليجاباً في زيادة مستويات التماثل التنظيمي لديهم. الكلمات المفتاحية: القيادة الاتوقراطية، انماط القيادة الاتوقراطية، التماثل التنظيمي، ابعاد التماثل التنظيمي

مـ اعتمـاد مختلف الأنماط القياديـة ألا وهـو عنصـر التـأثير في

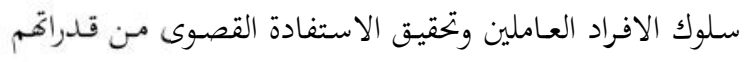

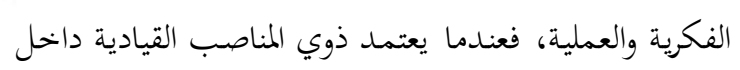

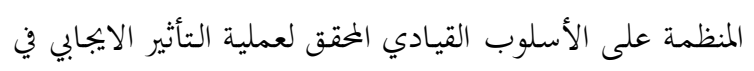

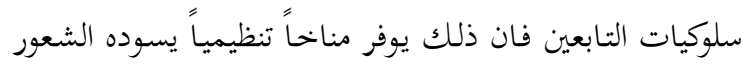
بالرضا والسرور والمودة بين صفوف الافراد العاملين داخل بيئة

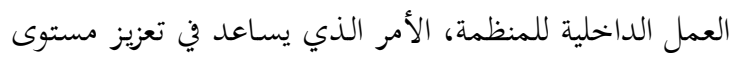

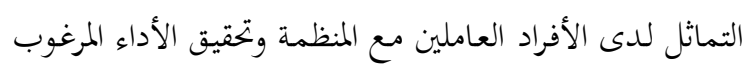

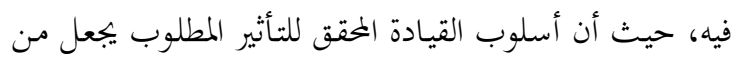

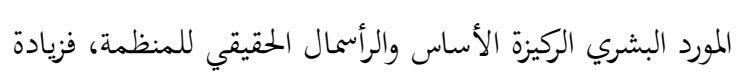

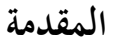

يعد التماثل التنظيمي للأفراد العاملين من المواضيع المهمة

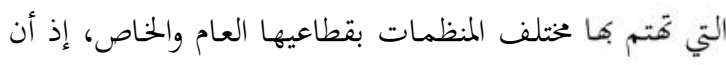
للتماثل التنظيمي تبعات ونتائج مهمة تؤثر في مستوى أداء

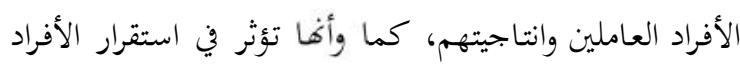

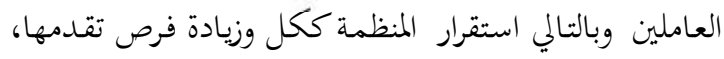
فكلما كان مستوى تماثل الافراد لمنظمتهم مرتفعاً كان هناك

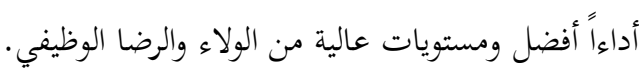

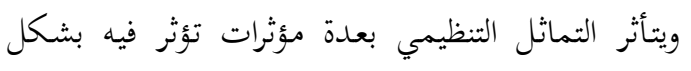

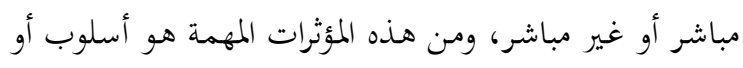
نمط القيادة الادارية الذي يعتمد عليه في تحقيق الركيزة الرئيسية 
في حـدود الادارة العليا فقط، الأمر الذي يؤدي في الكثير من الأحيـان الى ظهور حسالات مـن التوتر والتــمر لـدى التـابعين

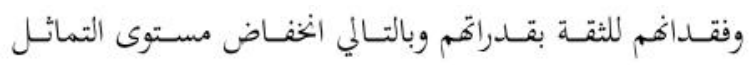
التنظيمي لديهم والذي يتضمن الخفاض الشعور بالانتماء والولاء

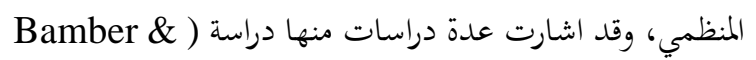

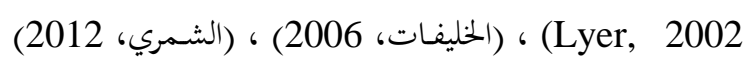

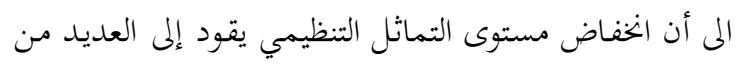

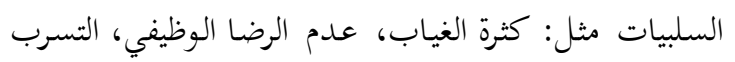

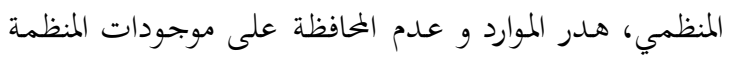

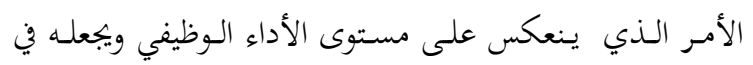

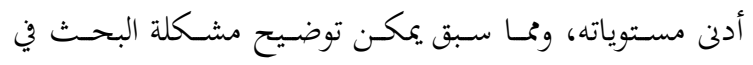

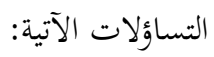

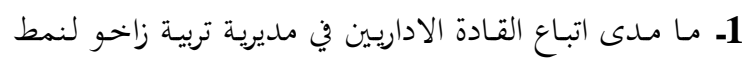

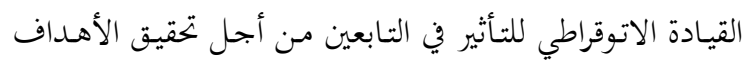
والوصول الم مستوى الأداء الأفضل ؟

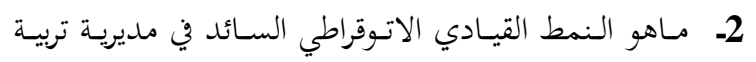
زاخو ؟ 3- مـا مستوى التماثل التنظيمي لدى أفراد العينة المبحوثة مـن موظفي مديرية تربية زاخو ؟ 4 هـل يمكـن تعزيز مستوى التماثـل التنظيمي لـدى الأفراد التابعين عن طريق استخدام النمط القيادي الاتوقراطي ؟ ؟ 5ـ مـاهي علاقـات الارتبـاط والتـأثير بـين القيـادة الاوتوقراطيـة

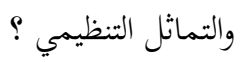

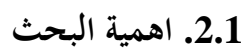

يمكن ابراز أهمية البحث الحالي من خلال النقاط التالية :

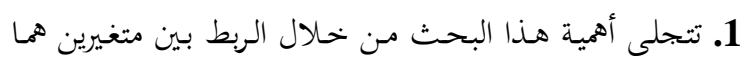

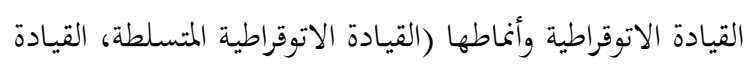

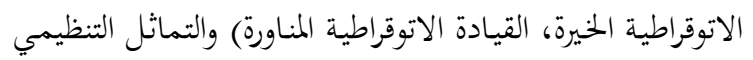

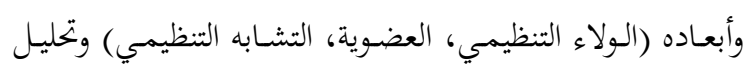
العلاقات الاحصائية بينهما.
مستوى التماثل التنظيمي يعد من المهام الرئيسية لقيادات المنظمات المعاصرة ونتيجة أساسية للنمط القيادي المعتمد. ومسن هـذا المنطلق يسعى البحتث الى الربط بـين موضوعين

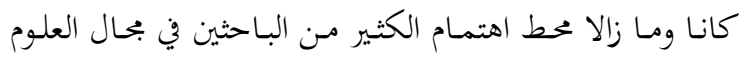

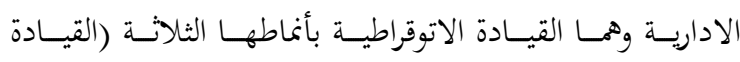

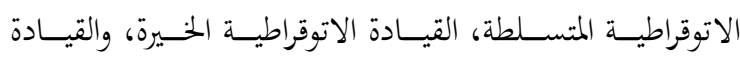

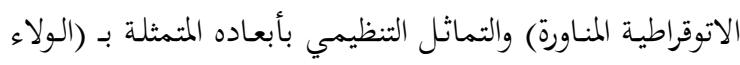

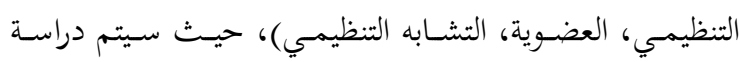
وتحليـل علاقـات الارتبـاط والتـاثير بــين الموضـوعين او المتغيرين لتحقيق الاستتفادة المعرفية التي ستحظى بكل تأكيد باهتمـام

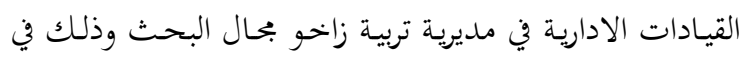
اختيار النمط القيادي المناسب والذي يساعد في توفير التماثل التنظيمي وتعزيزه لدى موظفي المؤسسة المبحوثة. وتم تقسيم البحث الم خمسة مباحث، تناول المبحث الأول

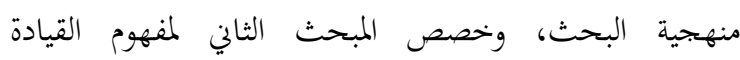
الاتوقراطية وأنماطها، بينما تطرق المبحث الثالث لمفهوم التماثل

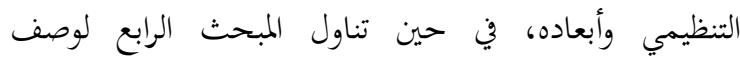
وتشخيص متغيري البحث وعرض وتحليل نتائج الارتباط والتأثير

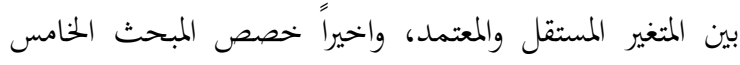
لأهم الاستنتاجات والمقترحات التي توصل اليها الباحثين.

\section{المبحث الاول}

\section{منهجية البحث}

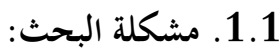

يسعى القادة الاداريين للوصول بـالأفراد العاملين الى تحقيق

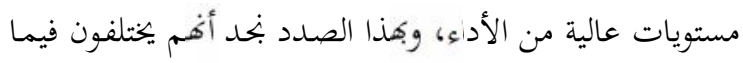

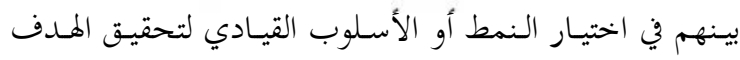

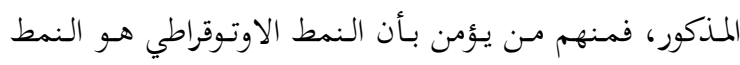

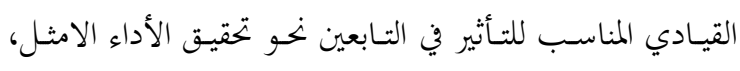
وذلك مسن خهلال الاعتماد على أساليب الضغط المباشر مثل

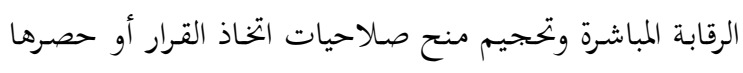


2ـ اختبار الأرتباط والتأثير بين انماط القيادة الاتوقراطية وأبعاد

$$
\text { التماثل التنظيمي. }
$$

3- تقــيم مقترحـات لادارة المؤسسـة المبحوثـة بخصـوص كيفيـة

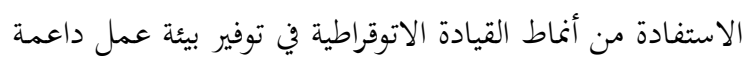
لتعزيز مستوى التماثل التنظيمي بين الافرد العاملين.

$$
\text { 4.1. فرضيات البحث }
$$

أ- الفرضية الرئيسة الاولى: توجد علاقة ارتباط ذات دلالة معنوية بين القيادة الاتوقراطية والتماثل التنظيمي. لوحئ. ب- الفرضية الرئيسة الثانية: توجد علاقة ارتباط ذات دلالة معنوية بين لكل نمط من أنماط القيادة الاتوقراطية وأبعاد التماثل التنظيمي. ج- الفرضية الرئيسة الثالثة: يوجد تأثير ذو دلالة معنوية للقيادة الاتوقراطية في التماثل التنظيمي. د- الفرضية الرئيسة الرابعة: يوجد تأثير ذو دلالة معنوية لكل نمط لكط من أنماط القيادة الاتوقراطية في أبعاد التماثل التنظيمي. 5.1 لتوضح العلاقات بين متغيري البحث، فانه تم صياغة مخطط فرضي يعكس تلـك العلاقـات، وكما مبين في الشكل (1) :
2. كما أن متغيري البحث تعد من المفاهيم الأساسية في بحال

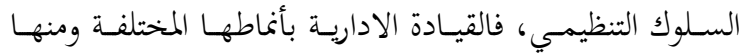
النمط الاوتوقراطي (وخاصة عندما يتم اعتماده بالشكل الخير او

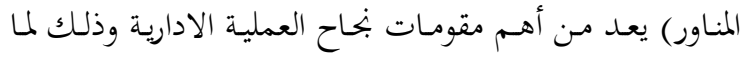

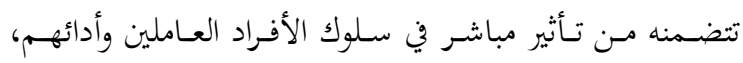
وكذلك التماثل التنظيمي الذي يعد مـ أهـم العوامل الداعمة

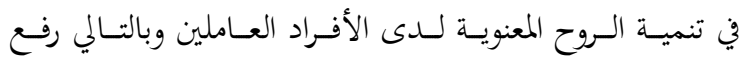
مستويات الانتماء والولاء لديهم مما يزيد من فرص بقاءهم في نفس المنظمة وتقديمهم لمستويات أداء افضل. 3. ومن جانب آخر فان النتائج التي يتوصل اليها البحث يمكن

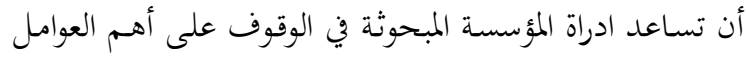

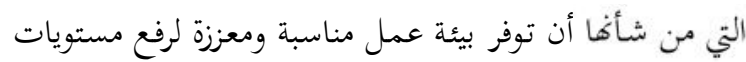
التماثل التنظيمي لموظفيها.

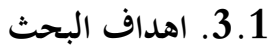
في ضوء مشكلة البحـث فـان هـدف البحـث يركز أساساً على تحديـد دور أنمـاط القيـادة الاوتوقراطيـة في تعزيـز التماثـل فئل التنظيمي لدى موظفي مديرية تربية زاخو بحال البحث، فضلا ليحل

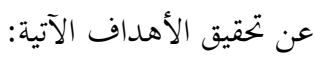
1- تقـــيم عـرض نظـري مفــاهيمي لمتغـيري البحــث المتمثلـين

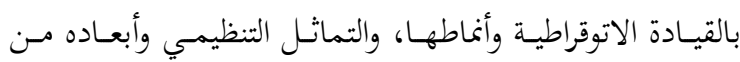
وجهة نظر عدد من الكتاب والباحثين.

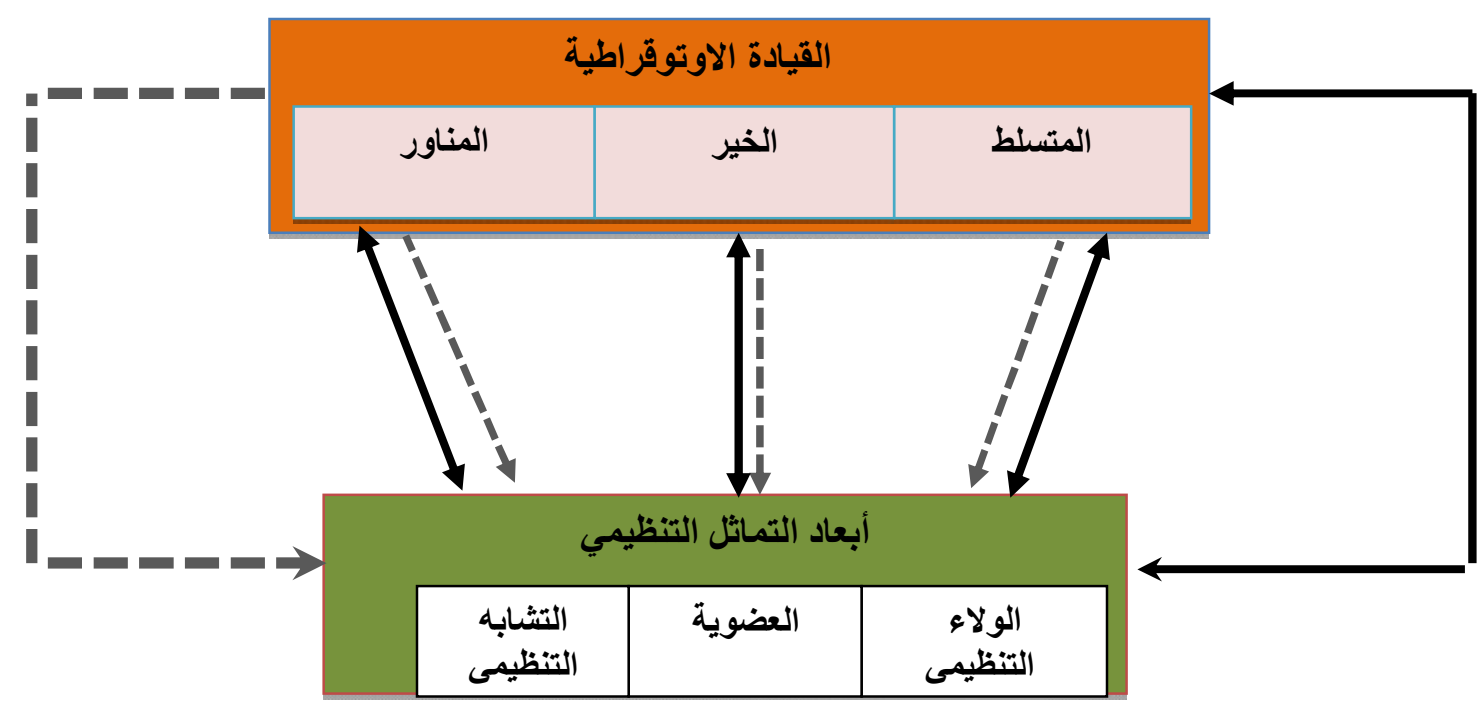




$$
\text { الشكل(1): خطط البحث الفرضي }
$$

تانير :

ارتباط :

الاتوقراطية في تعزيز مستوى التماثل التنظيمي لدى موظفي مديرية تربية زاخو.

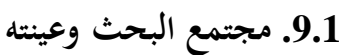

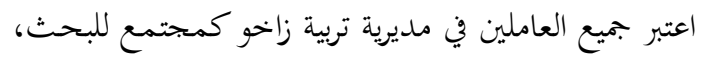

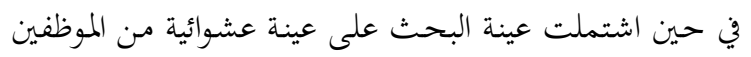

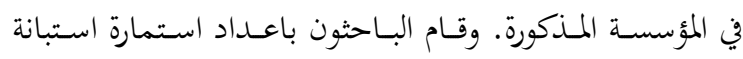
تكونت مس (30) فقـرة تمثل متغيري انماط القيـادة الاتوقراطية وأبعـاد التماثل التنظيمسي. ووزعـت الاستبانة على أفراد العينـة فئة

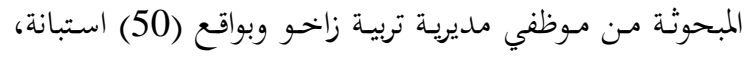

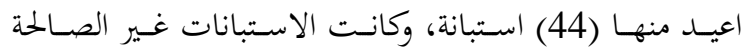
للتحليل (4) استبانات.

\section{1 اساليب التحليل الاحصائي}

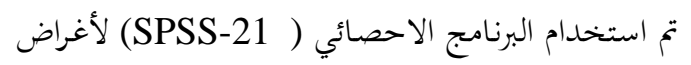

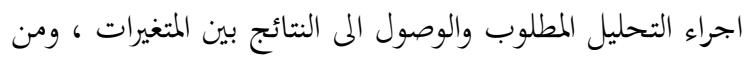

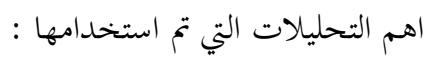

أ- التكرارات والنسـب المئويـة والمتوسطات الحسبـابية والانحرافـات

المعيارية.

ب- الارتباط البسيط لكشف العلاقة بين المتغيرين المبحوثين.

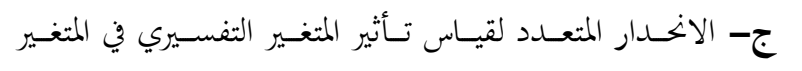

$$
\text { والمستجيب. }
$$

د- اختبار معنوية انموذج البحث وأبعاده اعتمادا على اختبارات

. (T) $g(\mathrm{~F})$

\section{البمحث الثاني \\ القيادة الاتوقراطية وأنماطها}

تعد القيادة جوهر العملية الإدارية ومفتاح بحاحها كوها تقوم

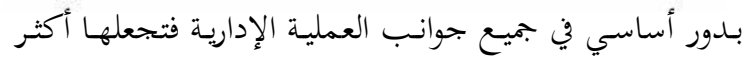

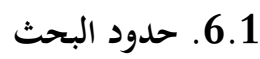

أ- الحـدود الزمانيه: تضمنت حسدود البحـث الزمانيه الفترة مـن 2018/4/15 لغاية 2018/10/1 .

ب- الحدود المكانية: تم اختيار مديرية تربية زاخو بحالاً للبحث. ج- الحدود البشرية: تم اختيار عينة عشوائية من موظفي مديرية

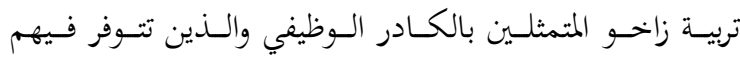
مقومات الحصول على البيانات والمعلومات المطلوبة.

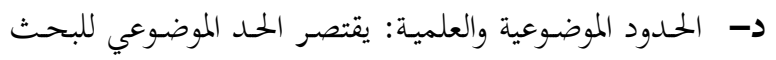

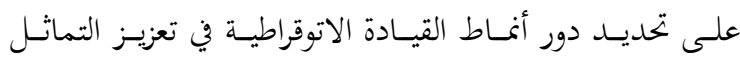
التنظيمي. 7.1 أساليب جمع البيانات

تم الحصول على البيانات المطلوبة للبحث عن طريق الآتي:

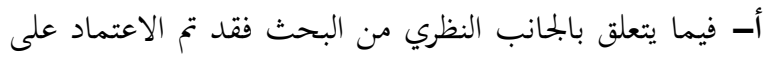

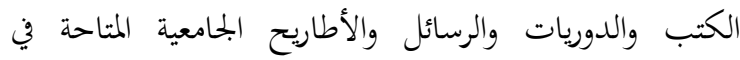
المكتبات وعلى شبكة الانترنيت والتي تمكن الباحثون من ولن

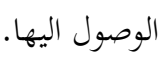
ب- أما بخصوص الجانب العملي من البحث فقد تم استخدام

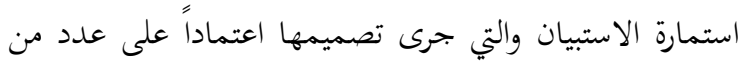

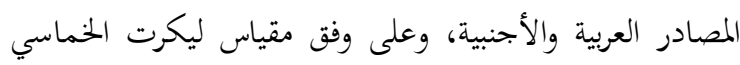
المتدرج من (موافق بشدة، موافق، محايد، غير موافق، غير موافق بشدة)

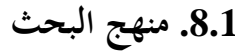

اعتمد البحث الحالي على المنهج الاستطلاعي، وذلك عن البك

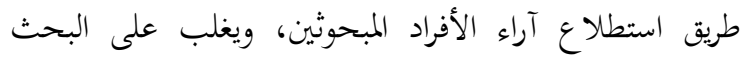

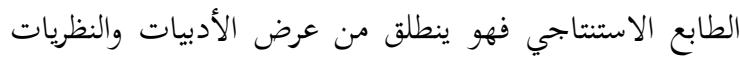
وصولاً الى تحليل الواقع، ويقوم البحث بدراسة دور أنماط القيادة 
180) الى أنه بالرغم مـن الانتقـادات الموجهة لأسلوب القيادة

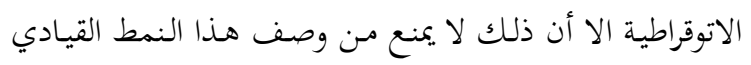

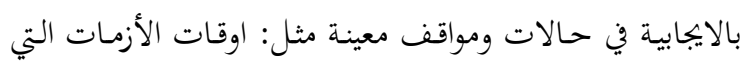
قد تتعرض فيها مصالح المنظمة للخطر والتي تحتاج لحلول سريعة واتخاذ قرارات بحدية، ولأن مثل هـذه المواقف لا تحتمل التـأخير

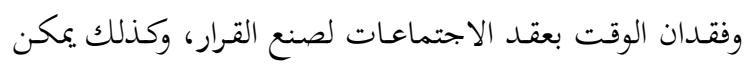

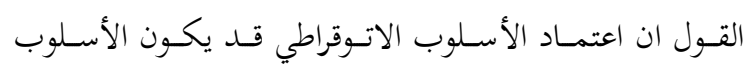

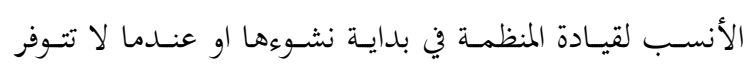

القدرات المطلوبة لدى التابعين للمشاركة في صنع القرارات.

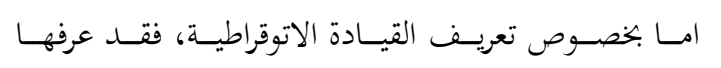

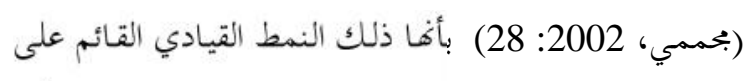

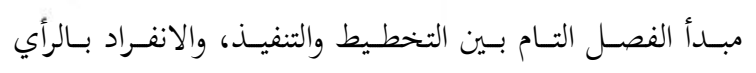

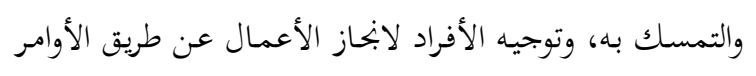

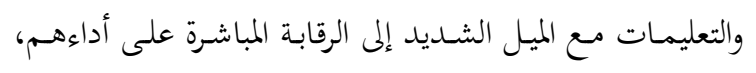

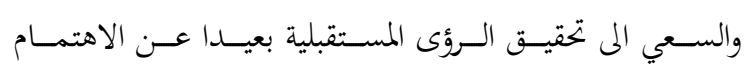

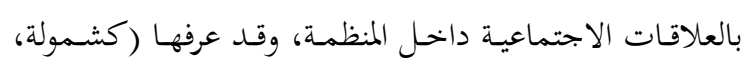
2007 : 17) بأها عملية سلوكية تتجه نحو تركيز سلطة اتخاذ القرارات بيد شخص واحد يفترض أن تكون درجة معرفته أكبر

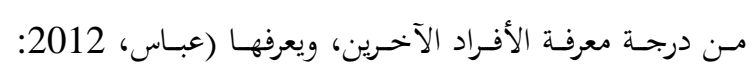

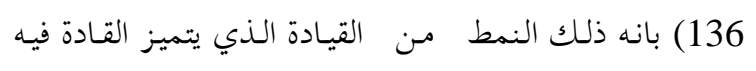

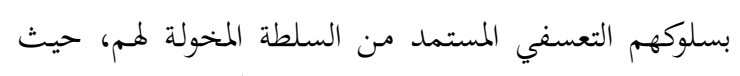

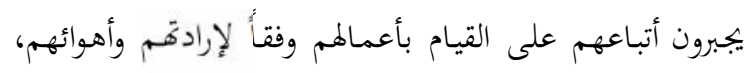
ويتمسكون بقراراتم دون الاستماع للأفكار او المقترحسات

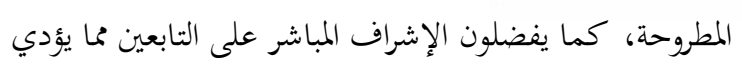

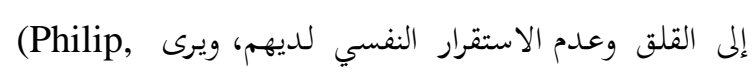

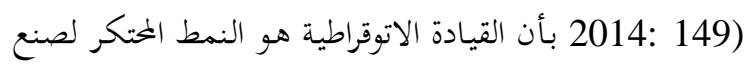

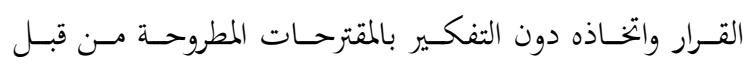

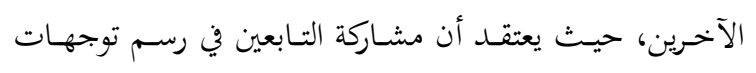

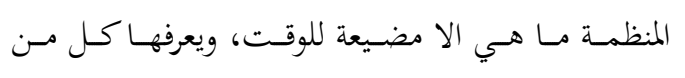

بأنه منهج لقيادة الأفراد التابعين (Khan,et.al, 2015: 57) وتوجيهم دون مشـاركتهم في وضـع السياسـات المطلوبـة لابجـاز
ديناميكية وفاعلية وتعمل كأداة محركة لجميع موارد المنظمة باتحاه

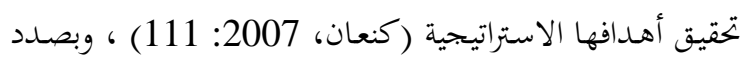

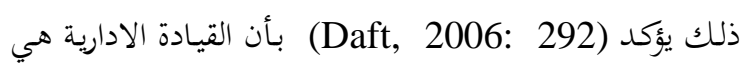

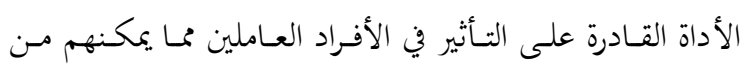

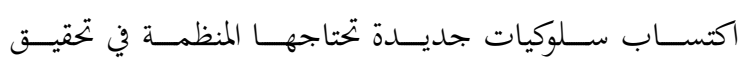

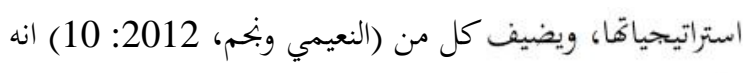

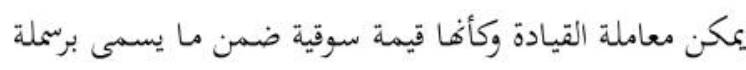

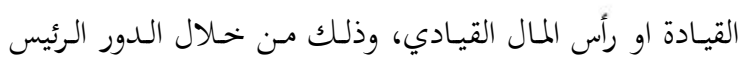

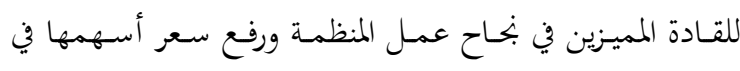

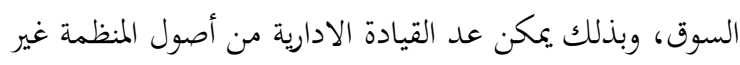

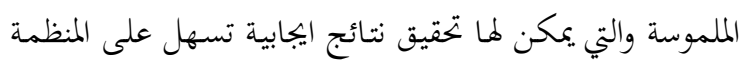
الوصول لأهدافها الاستراتيجية.

\section{The concept of مفهوم القيادة الاتوقراطيـة. 1.2 autocratic leadership} يطلق البعض على القيـادة الاوتوقراطيـة تسـميات متنوعـة،

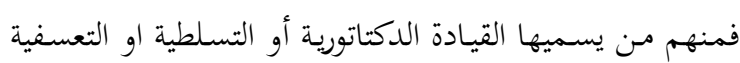

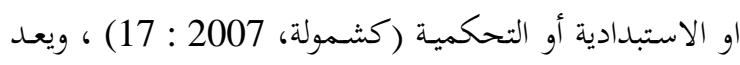

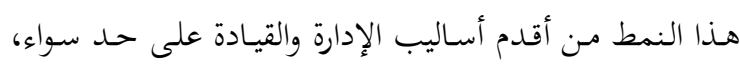

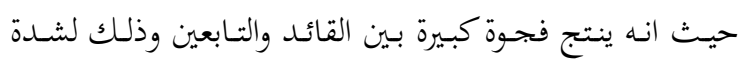

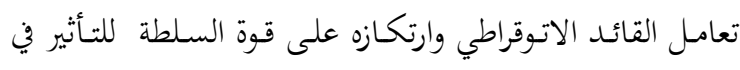

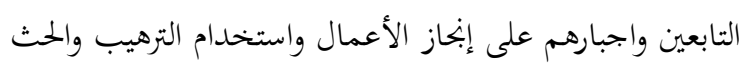

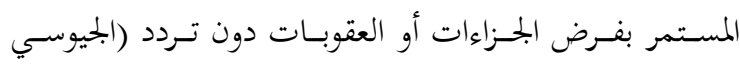

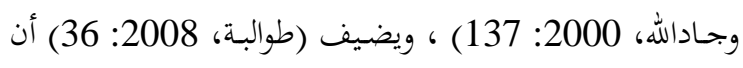
أكثر ما يميز اسلوب القائد الأوتوقراطي هو التخاذه من سلطنه الرسمية أداة للضغط على التابعين لإجبارهم على إبحاز الاعمال

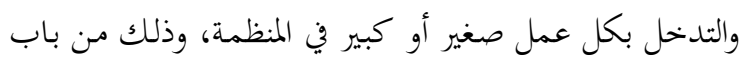

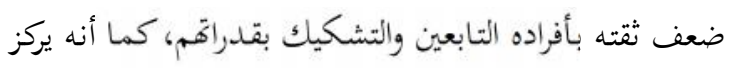

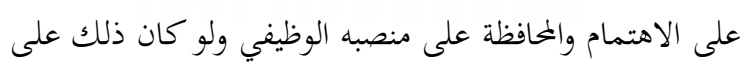

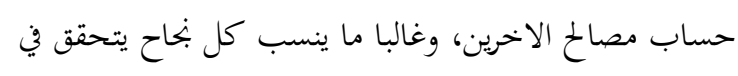

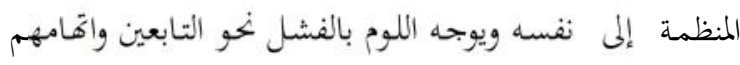

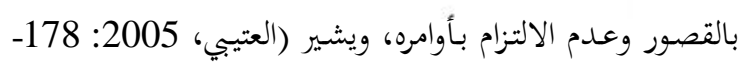


التهديد بالعقاب لضمان التزامهم بتنفيذ الاوامر الصادرة، وفي

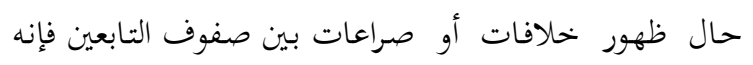

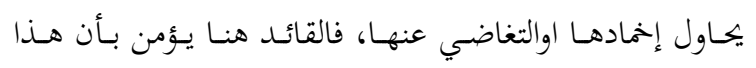

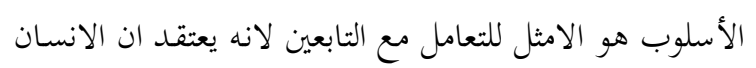

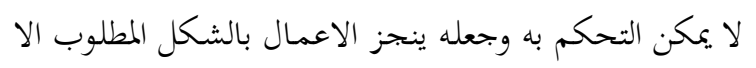

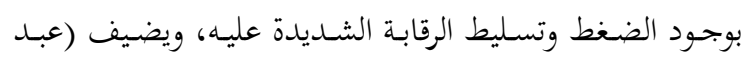

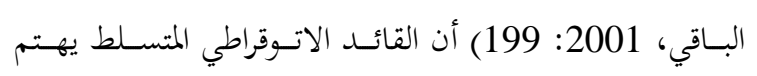

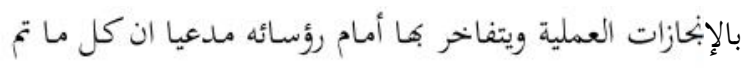
ابحازه هي نتاج جهوده الشخصية وذلك بهدف تحصين مركزه الوظيفي.

\section{Benevolent : 2.2.2 منط القيادة الاتوقراطية الخيرة} autocratic leadership style

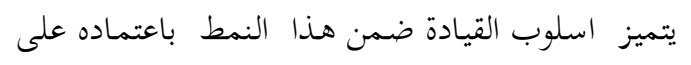

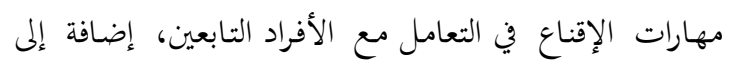

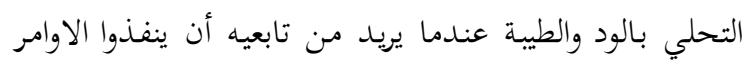

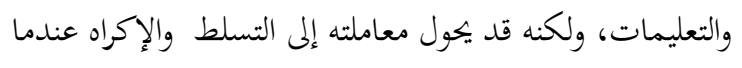

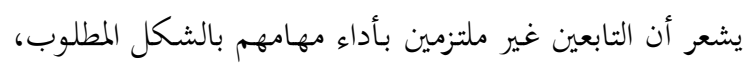

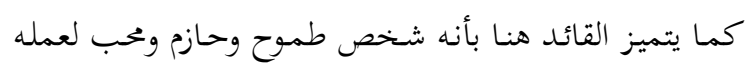
ويعمل على تحفيز تابعيـه للسـير على خطى أفكـاره القياديـة

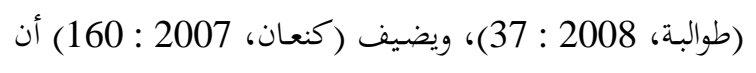
القائد الاتوقراطي الخير يوصف بأنه ذو قصد طيب مع التابعين

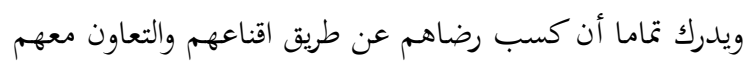

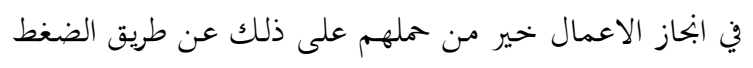

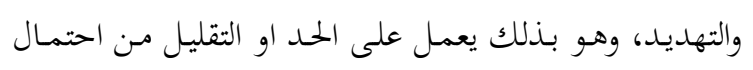

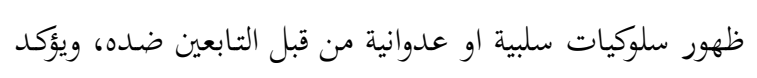
(ابـو بكــ، 2003: 423) ان القائسد الاتسوقراطي الخـير يمتــاز

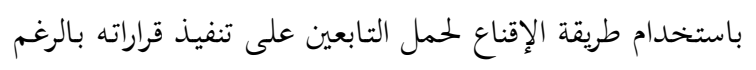

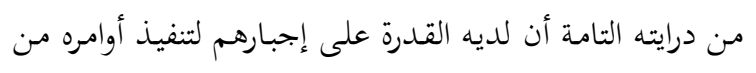

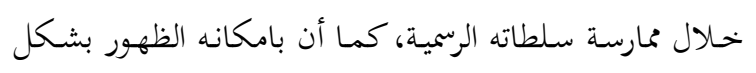
عادل في ممارسة سلطاته وتوزيع المهام بين التابعين وكذلك في بـاني نحديد مستحقاتهم من الثواب اوالعقاب.
الاعمال، حيث يعتقد القائد ضمن هذا النمط بأنه الشخص

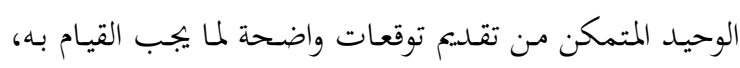
ومتى يجب القيام به، وكيف ينبغي على التابعين القيام به.

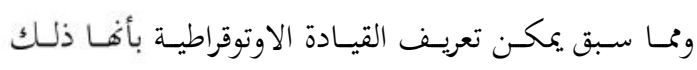

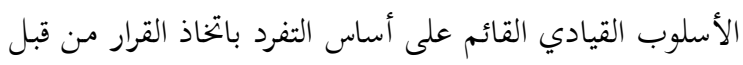

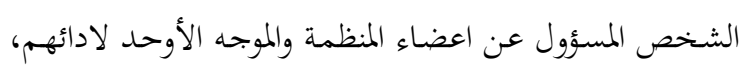

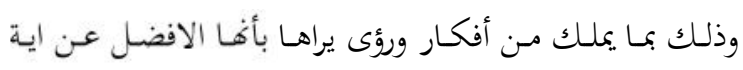
أفكار مقترحات اخرى مطروحة من قبل الآخرين.

\section{Autocratic أنمـاط القيـادة الاتوقراطيسة.}

leadership styles يتفـق عـدد مسن الكتـاب والمفكـرين ومسنهم (عبـد البـاقي،

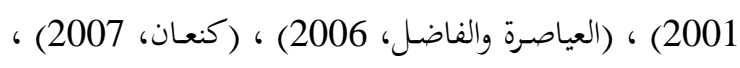

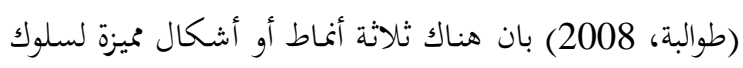

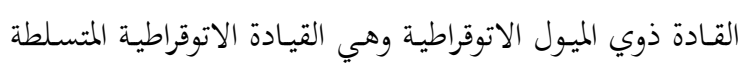

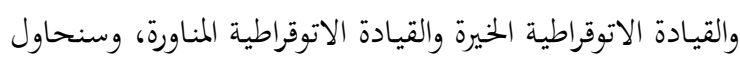

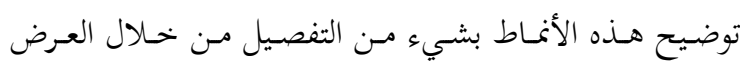

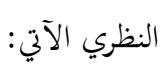

Authoritarian : 1.2.2 نمط القيادة الاتوقراطية المتسلطة: autocratic leadership style

يتميز هذا النمط بنظرته إلى الفرد العامل كأداة للعمل وكمصدر من مصادر الإنتاج، بغض النظر عن كونه مخلوقاً

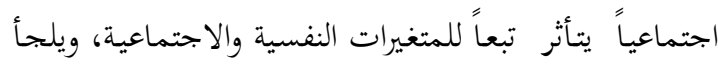
القائد هنا إلى استخدام سلطته المستمدة من منصبه الوظيفي

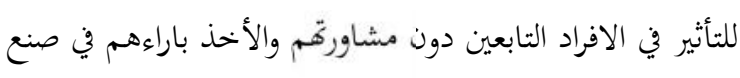

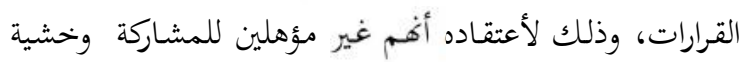
منه في ارتكابهم للأخطاء المؤدية للفشل الذي سيتحمله القائد في النهايـة (طوالبـة، 2008: 36) ، ، ويشـير كل مـن (العياصـرة

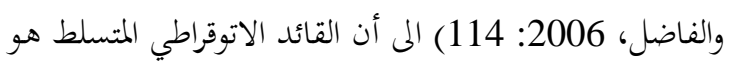

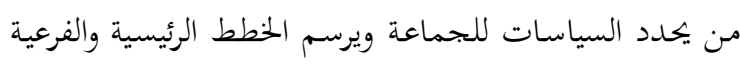

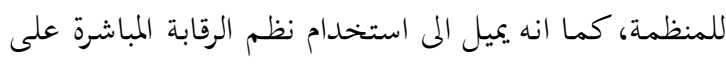

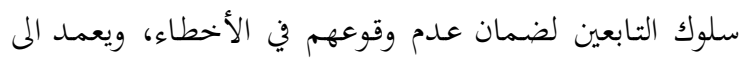


بينها للتأثير في الأفراد التـابعين بمـا يضـمن التزامهم بتنفيـذ مـا

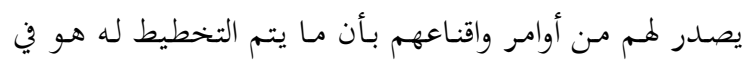
صالحهم وفي مصلحة المنظمة ككل، وكذلك بما تتطلب المواقف

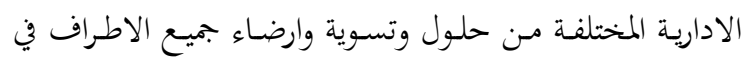

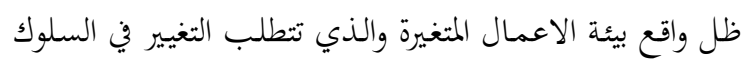
القيادي لتحقيق التكيف والبقاء والمنافسة.

المبحث الثاالث

مفهوم واهمية التماثل التنظيمي

Concept of مفهـوم التماثـل التنظيمي. 1.3 Organizational Symmetry يعد التماثل التنظيمي مس المواضيع الحديثة التداول ضـمن بحال نظرية المنظمة والسلوك التنظيمي بشكل خاص، بندي وقد تناوله الباحثون في الآونة الأخيرة كمتغير مهم في تفسير وتحديد طبيعة

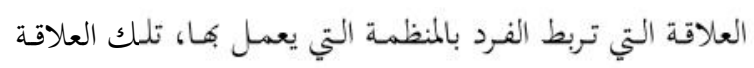

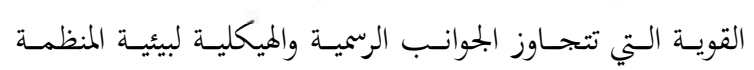
الداخلية (صالح، 2014: 59)، وقد اصبح تواجد التماند التماثل

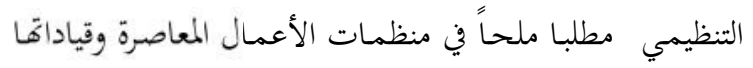

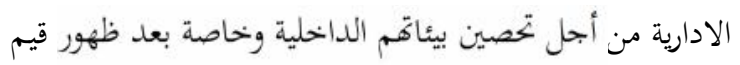

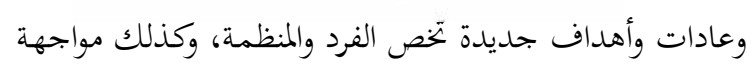

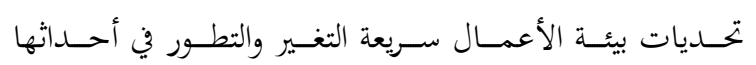

الاقتصادية والسياسية والاجتماعية (البشابشة، 2008: 428)

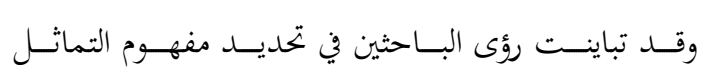

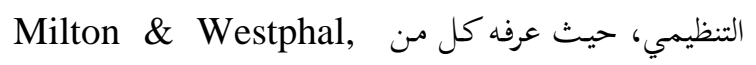

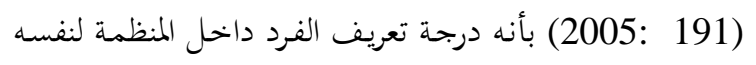
بنفس الخصائص التي يعتقد الفرد بأن المنظمة تعرفه بها، والتي

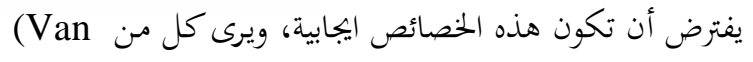

Maneuver : 3.2.2 منط القيـادة الاتوقراطيـة المنـاورة autocratic leadership style ينظر الى هذا النمط بأنه من أقل الأنماط الأوتوقراطية من

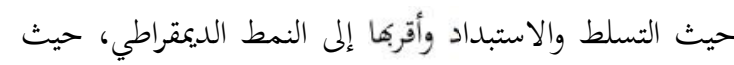

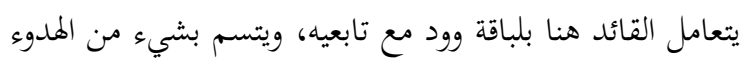

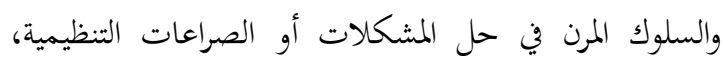
ويعتقد هذا القائد أن مشاركة التابعين في صنع القرارات وسيلة غير بحدية، لكنه يعمل على ذلك بمدف توان توافر الشعور بالمشاركة

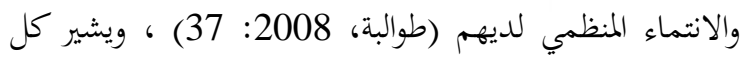

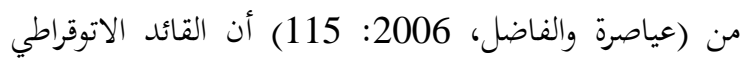
المناور يعتمد على اسلوب ما يسمى بالمؤتمرات الاخبارية والتي

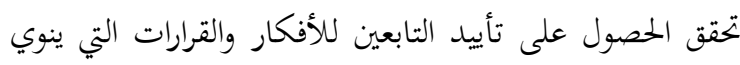

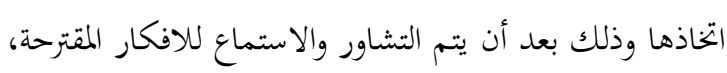

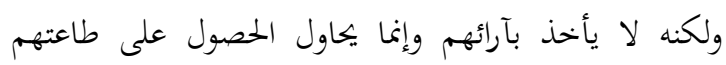
وجعلهم يشاركون بفعالية في عملية صنع القرار، ويبين (أبو

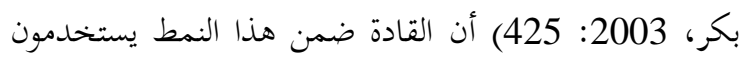
أساليب تكتيكية للتأثير في التابعين أهمها اللباقة في التعامل وخاصة عندما يدركون ان هذه الاساليب ضرورية لتوليد الاحساس بالمشاركة لديهم وجلبهم ضمن العندم: العملية الادارية وبالتالي الحصول على الاداء المرغوب فيه.

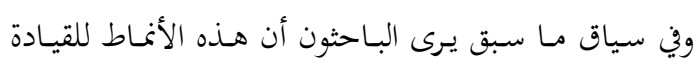
الاتوقراطية يمكن عدها كمستويات أو درجات للسلوك المتشدد

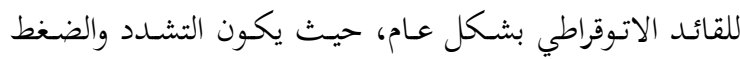
على التـابعين في أعلى مستـوياته في حسال الـنمط الاتـوقراطي المتسلط من خهلال التفرد بالقرار واهمال قدرات التابعين، وقد فئد يكون هـذا الضغط أقل في حسال النمط الاتوقراطي الخير، وأمـا

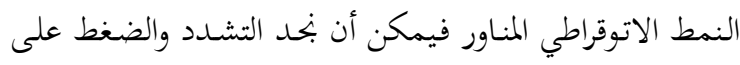
التابعين في أدنى مستوياته وذلك لمنحهم فرصاً للمشاركة في ابداء

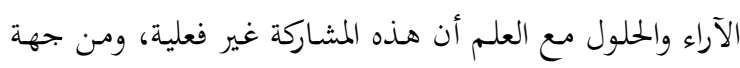
انخرى فانه يمكن للقائد الاداري المعاصر وذو الميول الاتوقراطية أن يعتمد على هذه الأنماط وأن يمتلك القدرة على التحول فيما 
يمكـن أن تتحقق فوائسد عديـدة للفـرد مـن خهلال التماثل التنظيمي والتي يمكن ذكر اهمها فيما يلي: (صـالح، 2014:

$$
\text { 64-63) (الشواورة، 2016: 124) }
$$

1. تعزيز احترام الذات: يرتبط احترام الفرد لذاته ارتباطاً قويـاً

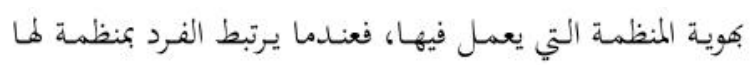

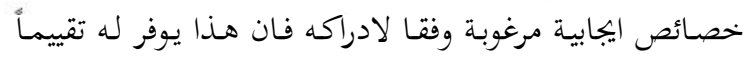

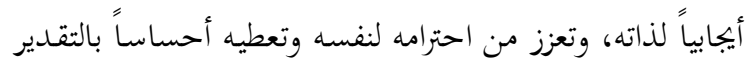
والأهمية.

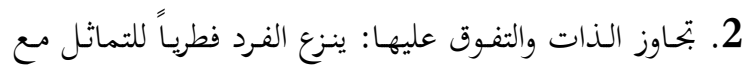

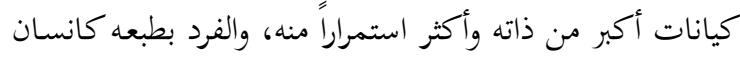
يرغب المشاركة والإسهام في أشياء يعـدها أكبر منه، فالتماثل

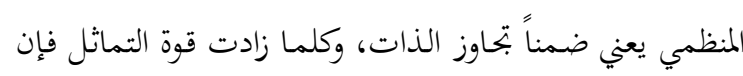

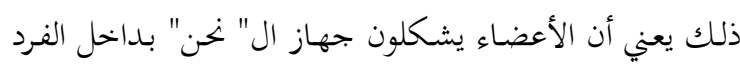

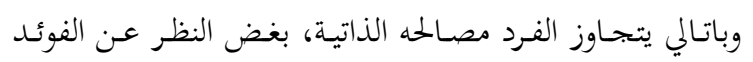

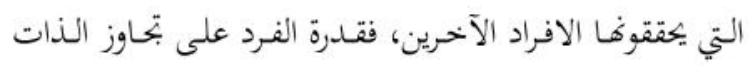

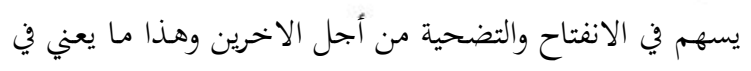
ثاية المطاف انسجام الفرد مع ذاته ومحيطه.

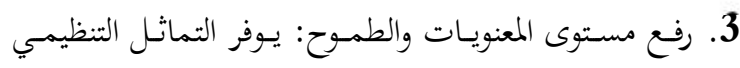

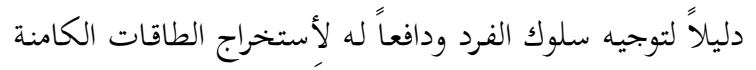

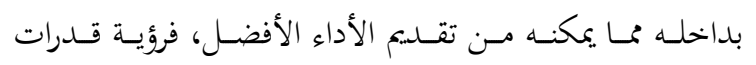

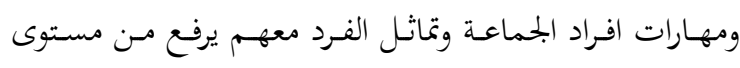

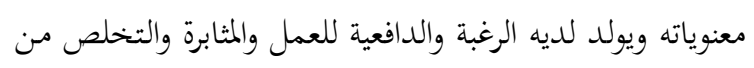

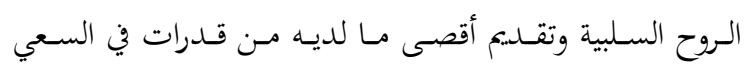
المتواصل لتحقيق النجاحات على المستوى الفردي والجماعي.

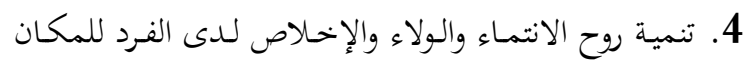

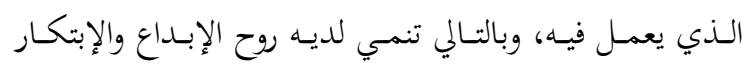

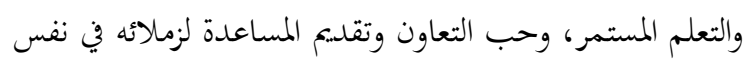

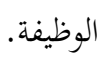

\subsection{3 أهمية التماثل التنظيمي للمنظمة:}

لا يقتصر التماثل التنظيمي في تحقيق المنافع للفرد فقط، فهو

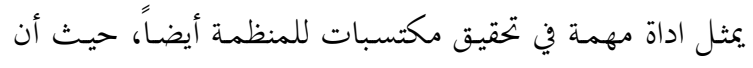

( Sleebos, 2006: 537)

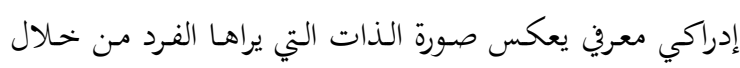

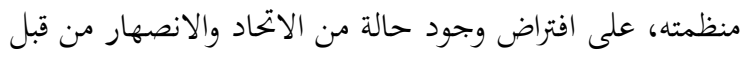
الفرد مع المنظمهة، ومسن خهلال ذلك يمثل الفرد والمنظمة كياناً

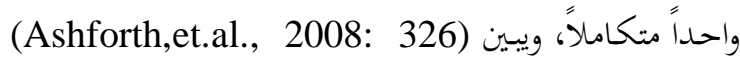
بأن التماثل التنظيمي عبارة عن ادراك عاطفي للفرد بعضويته

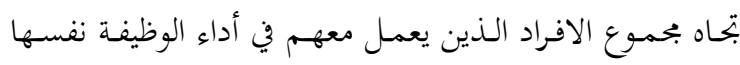

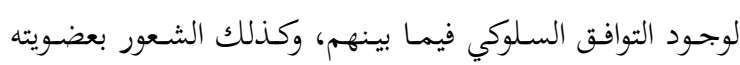

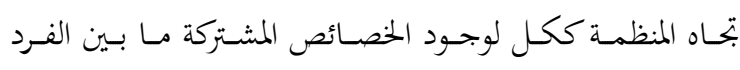

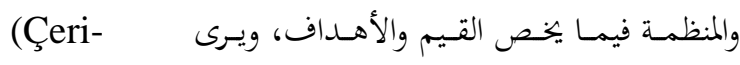
بأنه شعور الفرد بأنه جزء مـ Booms, 2012: 178)

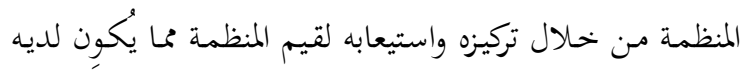

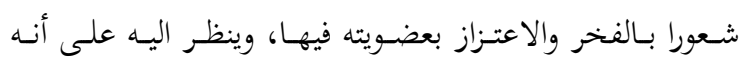

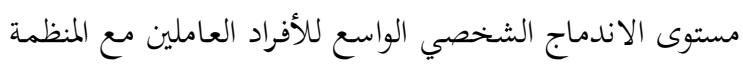

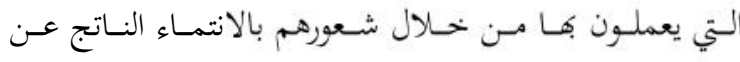

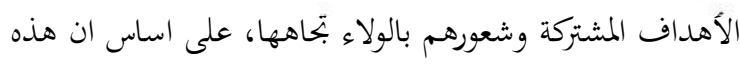

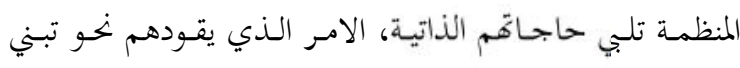

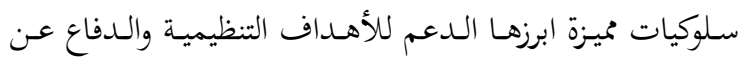
مصالح المنظمة (صالح، 2014: 60). وعلى ضوء ما سبق يرى الباحثون أن التماثل التنظيمي يمثل حالة من الادراك العاطفي والسلوكي للفرد بانتماءه للمنظمة التي لئي يعمل بها، حيـث يظهر الفـرد مـدى حبه وولائه لوظيفته وأداء

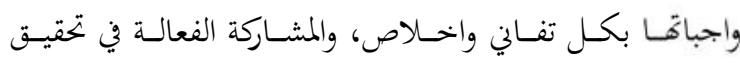

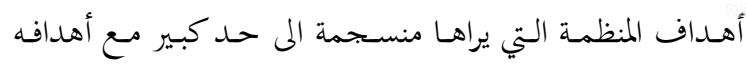

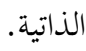

2.3. أهمية التماثل التنظيمي. التية. Organizational Symmetry للتماثل التنظيمي أهمية كبيرة بما يحققه من منافع مهمة سواء

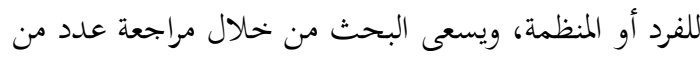
الأدبيات تحديد هذه الاهمية في سياق الاتي: 1.2.3. أهمية التماثل التنظيمي للفرد: 
ويجله موضع ثقة في اعتبارات رؤسائه، مما يساعد على تضاعف

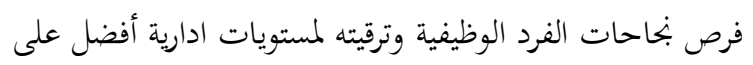

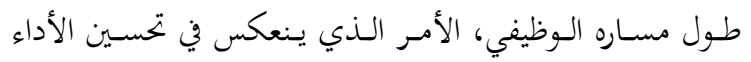
الكلي للمنظمة وتمكنها من تحقيق الاهداف التى تسعى اليها.

Dimensions of ابعاد التماثل التنظيمي. Organizational Symmetry يتفق عدد من الباحثين في العلوم الادارية أمثال: (الخليفات,

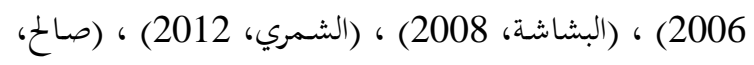
2014) ، (النزاري، 2016) (النئة، 2008) ، على أن التماثل التنظيمي يتكون،

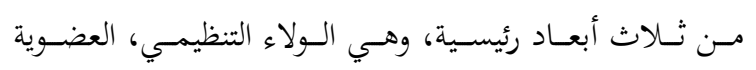
(الانتماء)، التشابه التنظيمي، وفيما يلي عرض لهذه الابعاد:

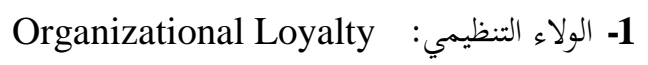

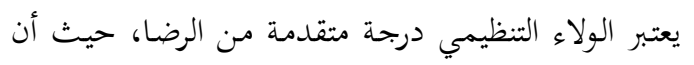

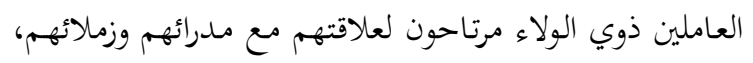

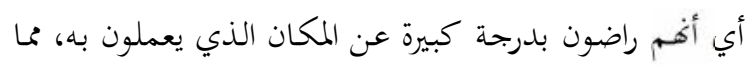

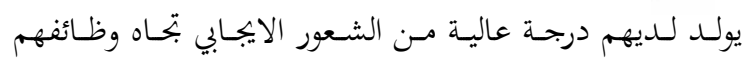

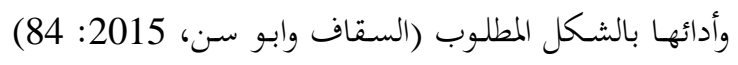
وقـــــــــن (كــاظم، 2014: 66) أن باسـتطاعة القــادة في

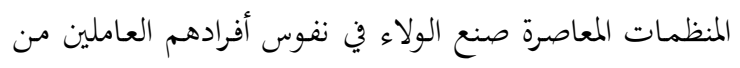

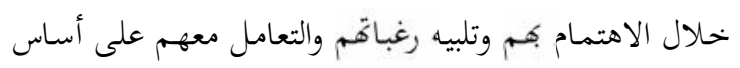
الاحترام والتقدير بما يعزز قدارتم الوظيفية، فضلاً عن إفساح

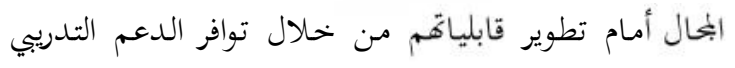
والتعلم المستمر، ويشير (Pandey \& Khare, 2012:27)

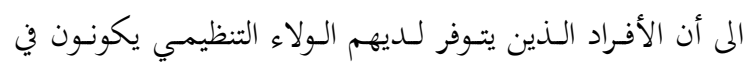

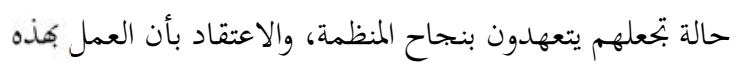

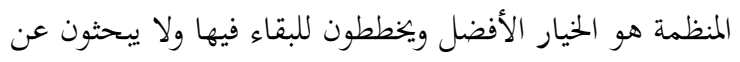

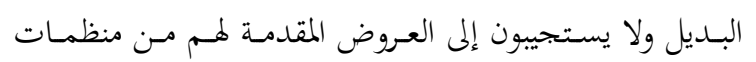
انخرى. (n)

2-2 العضوية (الانتماء): Membership

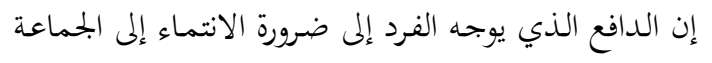

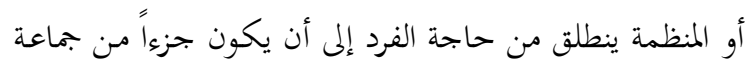

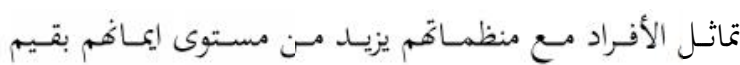

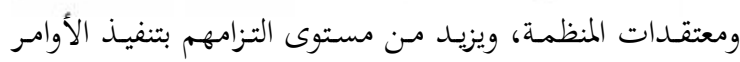
والقوانين الصادرة، والانحاز فوق المتوقع للمهام الوظيفية، والرغبة ونية

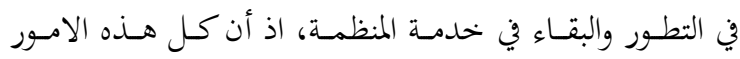
تصب في مصلحة المنظمة على المدى الطويل في تسهيل تحقيق

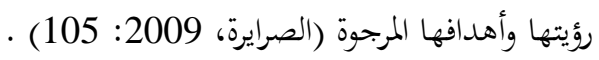
ويشـير (النزاري، 2016: 78) أن أهميـة التماثل التنظيمي بالنسبة للمنظمة تتمثل في الجوانب الاتية: 1. تسهيل عمليـة اتخـاذ القـرار: عندما يشعر الافراد العـاملين

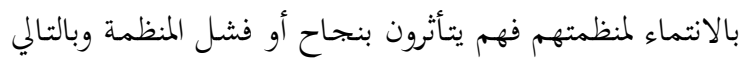

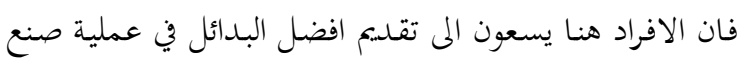
القرار. 2. تحسين مكانة المنظمة في البمتمع ورفع قدرقا التنافسية: فالفرد

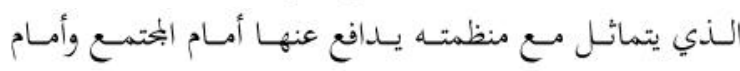
المنظمات الأخرى ويبـذل أقصى جهـده ليحقق أهـدافها وهـذا

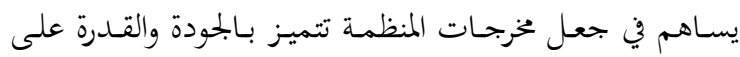
المنافسة في ظل عولمة الأسواق القائمة على المنافسة الشديدة.

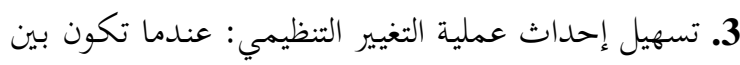

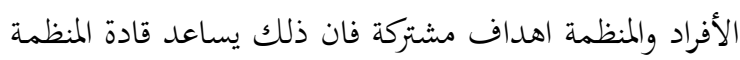
على اجراء عمليات التغيير الهيكلية داخل المنظمة دون اللجوء

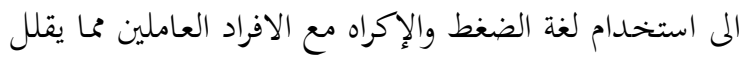
من حدوث حالات مقاومتهم للتغيير. 4. التماثل المنظمي يساهم في تحسين التغذية العكسية: فالأفراد الـذين يتمـاثلون مـع المنظمـة يصسبحون مهتمـين بشـكل أكسبر بالقضايا الخاصة بالنسبة للمنظمة التي يعملون فيها، مثل سمعة

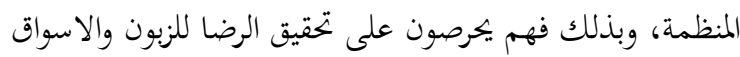
التي تتعامل معها المنظمة. وفي سياق ما سبق يرى الباحثون أن هناك جملة مـ المنافع التي يمكن أن تتحقق للفرد عن طريق تماثله التنظيمي مثل زيادة

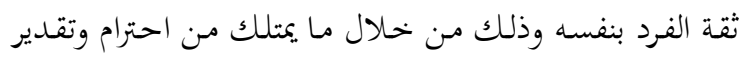
لذاته وكذلك بما يملك من قدرات ومهارات يقتنع بها الآخرين 


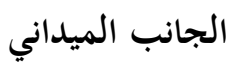 \\ 1.4. وصف متغيرات البحث.}

1.1.4. وصف متغير انماط القيادة الاتوقراطية.

1.1.1.4 النمط الاتوقراطي المتسلط.

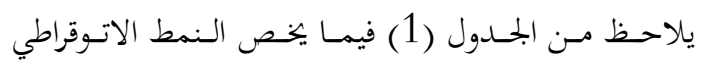

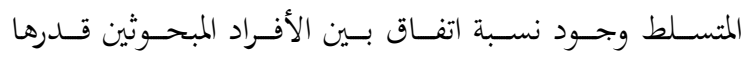

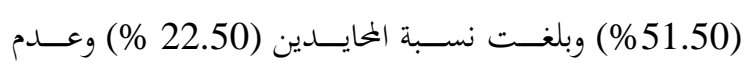

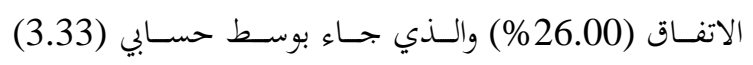

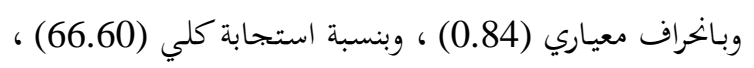

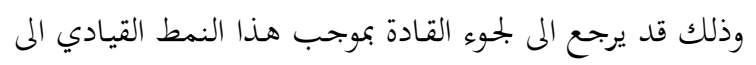

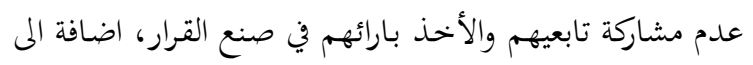

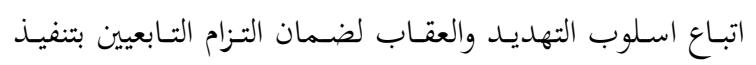

الاوامر والقرارات التي يصدرها القائد . ومن بين أهم المؤشرات

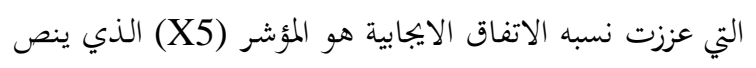

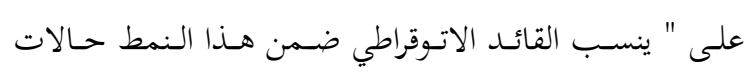

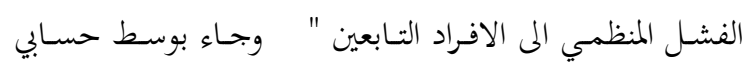

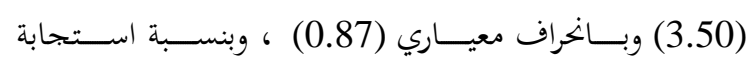

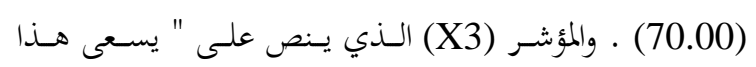

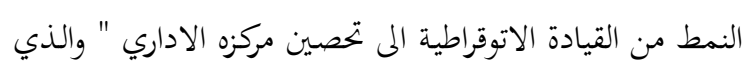

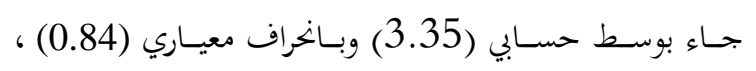

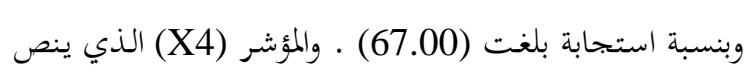

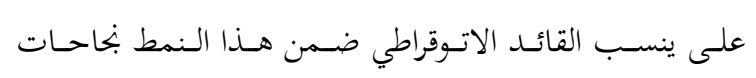
المنظمة لجهوده الشخصية " والذي جاء بوسط حسابي (3.33) وبانحراف معياري (0.84) ، وبنسبة استجابة (66.50) . 2.1.1.4 والنمط الاتوقراطي الخير.

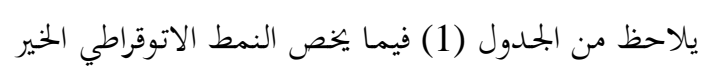

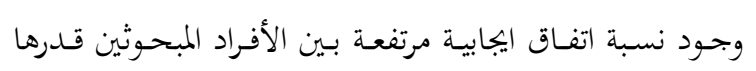

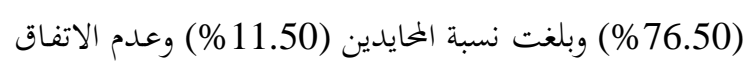

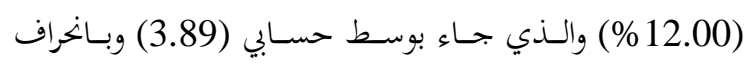

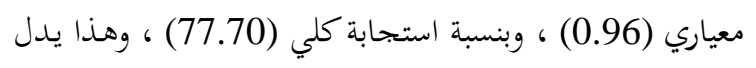

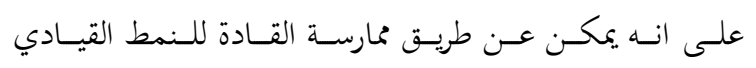

من الناس أو من وحدة أجتماعية، أي أن يكون مقبولاً من قبل

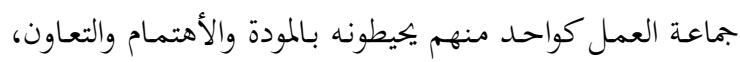

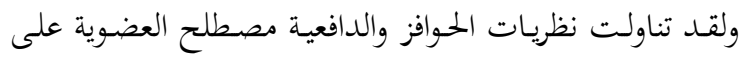

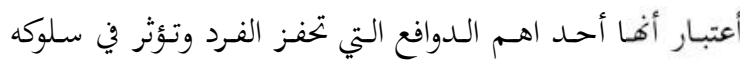

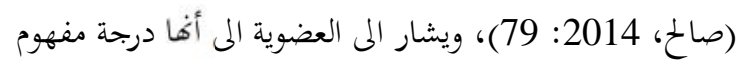

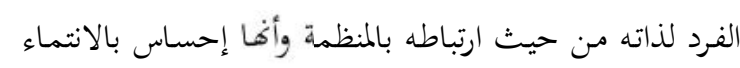

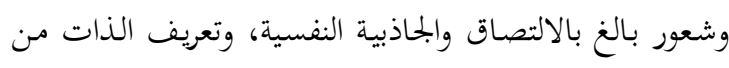

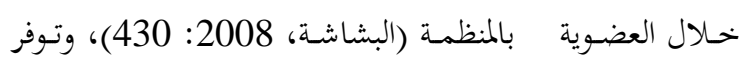
العضوية أو الانتماء التنظيمي لدى الفرد يجعله يشعر بأنه جزء

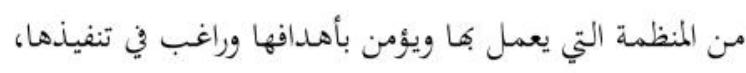

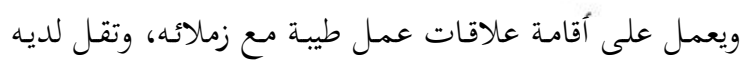

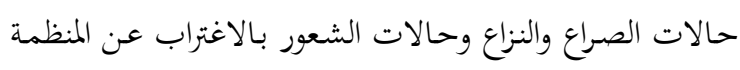

$$
\text { (الخليفات, 40:2006). }
$$

3- التشابه التنظيمي: Organizational similarity

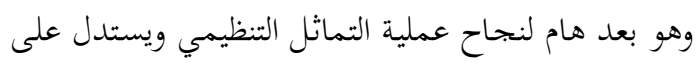

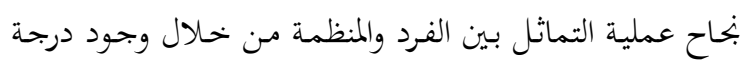
كبيرة من التشابه بين قيم وأهداف ورغبات ومصالح كلا الطرفين (الخليفات , 42:2006)، وان الأفراد يدركون التشابه مع الأفراد

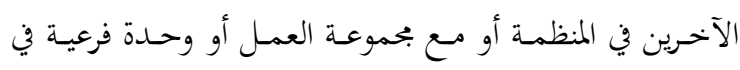

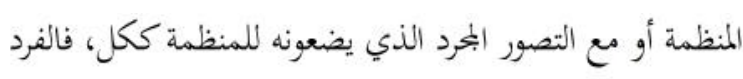

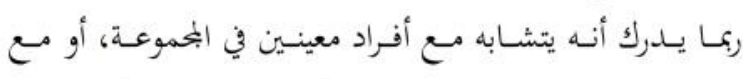

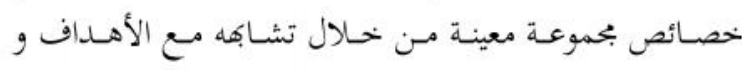

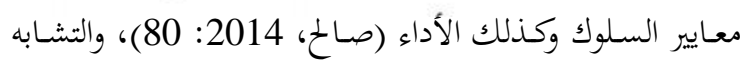

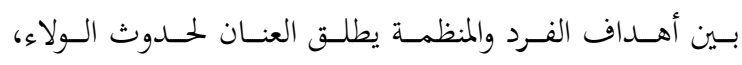

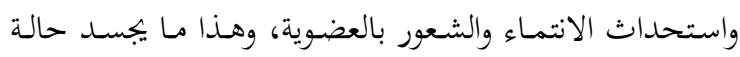

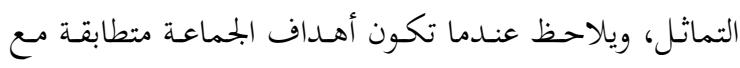

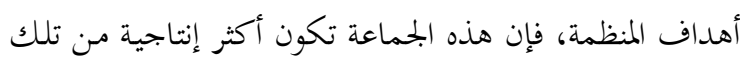

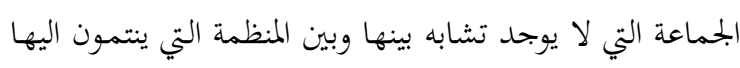

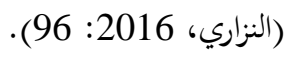


(\%64.00) وبلغت نسبة المحايدين (23.50) وعدم الاتفاق

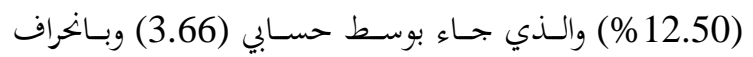

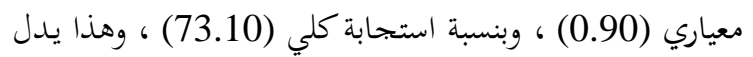
على ان النمط القيادي الاتوقراطي المنـاور يكظى برضـا الافراد التابعين وذلك من خحلال مناقشتهم ومشاركتهم في صنع القرار

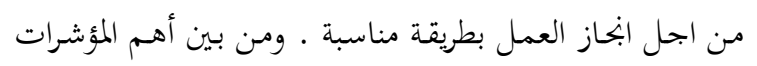

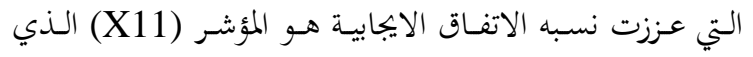

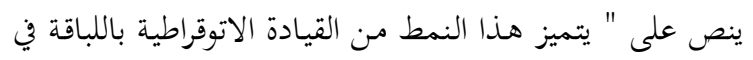
التعامل مع افرادها التابعين " وجاء كله بوسط حسابي (3.98) وبــانخراف معيساري (0.99) ، وبنسـبة اسـتجابة (79.50) .

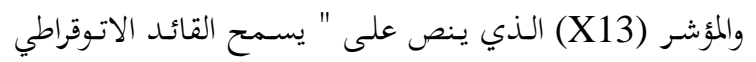

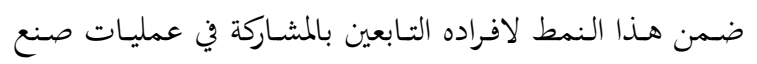
القرار " والذي جاء بوسط حسابي (3.75) وبانحراف معياري

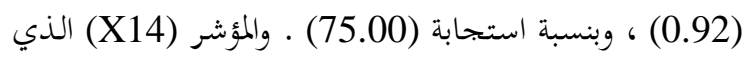

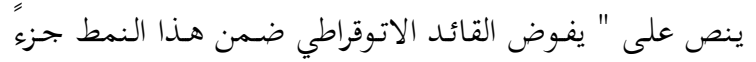

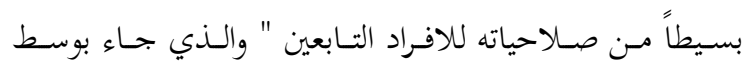
حسابي (3.63) وبانحراف معياري (3.89) ، وبنسبة استجابة

.(72.50)
الاتوقراطي الخير كسب ود وولاء الافراد التابعين بشكل افضل ودفنهم للعمل بتفـاني اكسبر وذلك مـن خهال الاخهـ بـارائهم

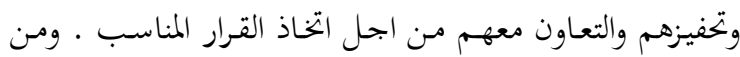

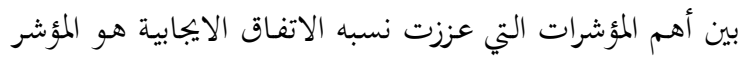

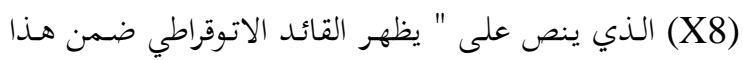

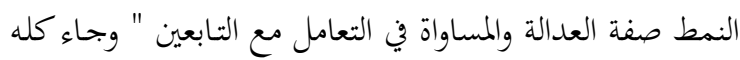
بوسط حسـابي (4.10) وبـانحراف معيـاري (1.03) ، وبنسبة

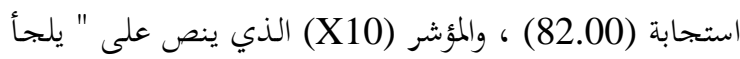

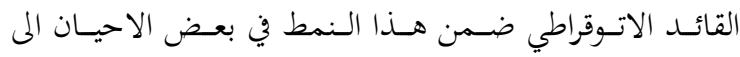
استخدام الضغط والتهديد مع التابعين للقيام بمهامهم الوظيفية " والذي جاء بوسط حسابي (3.98) وبانحراف معياري (0.99)

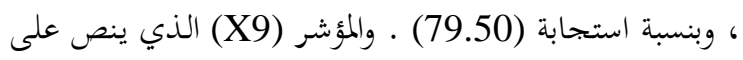

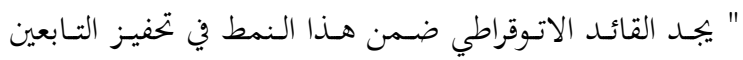
طريقـا جيـدا لتوليد الرغبة والدافعية لديهم نهو ابحـاز الاعمـال

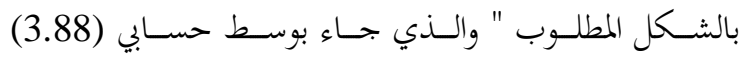
وبانحراف معياري (0.96) وبنسبة استجابة (77.50). 3.1.1.4 النمط الاتوقراطي المناور. يلاحظ من الجحدول (1) فيما يخص النمط الاتوقراطي المناور

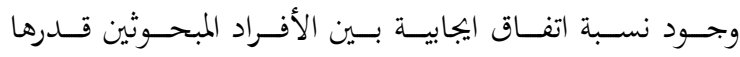


جدول (1): التكرارات والنسب المئوية والأوساط الحسابية والانحرافات المعيارية لانماط القيادة الاتوقراطية

\begin{tabular}{|c|c|c|c|c|c|c|c|c|c|c|c|c|c|c|}
\hline \multicolumn{14}{|c|}{ التوزيعات التكرارية والنسب المئوية لنمط القيادة الاتوقراطية المتسلط } & $\overline{3}$ \\
\hline \multirow[t]{2}{*}{ 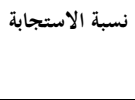 } & \multirow{2}{*}{ الالنحراف } & \multirow{2}{*}{ الحسابي } & \multicolumn{2}{|c|}{ لا لا اتفق بشدة } & \multicolumn{2}{|c|}{ لا لا تفق } & \multicolumn{2}{|c|}{ محايد } & \multicolumn{2}{|c|}{ اتفق } & \multicolumn{2}{|c|}{ 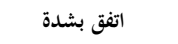 } & \multirow[t]{2}{*}{ المؤشر } & 5 \\
\hline & & & $\%$ & التكرار & $\%$ & التكرار & $\%$ & التكرار & $\%$ & التكرار & $\%$ & التكرار & & $y$ \\
\hline 63.00 & 0.82 & 3.15 & 15.0 & 6 & 15.0 & 6 & 27.5 & 11 & 25.0 & 10 & 17.5 & 7 & $\mathrm{X} 1$ & \\
\hline 66.50 & 0.84 & 3.33 & 17.5 & 7 & 10.0 & 4 & 17.5 & 7 & 32.5 & 13 & 22.5 & 9 & $\mathbf{X} 2$ & \\
\hline 67.00 & 0.84 & 3.35 & 17.5 & 7 & 7.5 & 3 & 25.0 & 10 & 22.5 & 9 & 27.5 & 11 & $\mathrm{X} 3$ & \\
\hline 66.50 & 0.84 & 3.33 & 12.5 & 5 & 15.0 & 6 & 17.5 & 7 & 37.5 & 15 & 17.5 & 7 & $\mathbf{X} 4$ & 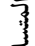 \\
\hline 70.00 & 0.87 & 3.50 & 12.5 & 5 & 7.5 & 3 & 25.0 & 10 & 27.5 & 11 & 27.5 & 11 & X5 & $d$ \\
\hline \multirow[t]{2}{*}{66.60} & 0.84 & 3.33 & \multicolumn{2}{|c|}{15.00} & \multicolumn{2}{|c|}{11.00} & \multicolumn{2}{|c|}{22.50} & \multicolumn{2}{|c|}{29.00} & \multicolumn{2}{|c|}{22.50} & المؤشر & \\
\hline & & & \multicolumn{4}{|c|}{26.00} & \multicolumn{2}{|c|}{22.50} & \multicolumn{4}{|c|}{51.50} & 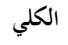 & \\
\hline \multicolumn{14}{|c|}{ التوزيعات النكرارية والنسب المئوية لنمط القيادة الاتوقراطية الخير } & $\overline{3}$ \\
\hline 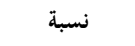 & 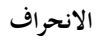 & الوسط & \multicolumn{2}{|c|}{ ل الا اتفق بشدة } & \multicolumn{2}{|c|}{ لا لاتفق } & \multicolumn{2}{|c|}{ محايد } & \multicolumn{2}{|c|}{ اتفق } & \multicolumn{2}{|c|}{ اتفق بشدة } & 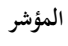 & 5 \\
\hline 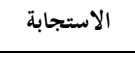 & 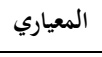 & الحسابي & $\%$ & التكرار & $\%$ & التكرار & $\%$ & التكرار & $\%$ & التكرار & $\%$ & التكرار & & b \\
\hline 77.50 & 0.96 & 3.88 & 5.0 & 2 & 7.5 & 3 & 10.0 & 4 & 50.0 & 20 & 27.5 & 11 & $\mathrm{X6}$ & \\
\hline 72.00 & 0.89 & 3.60 & 2.5 & 1 & 22.5 & 9 & 10.0 & 4 & 42.5 & 17 & 22.5 & 9 & $\mathrm{X7}$ & \\
\hline 82.00 & 1.03 & 4.10 & 2.5 & 1 & 5.0 & 2 & 5.0 & 2 & 55.0 & 22 & 32.5 & 13 & $\mathrm{X} 8$ & \\
\hline 77.50 & 0.96 & 3.88 & 5.0 & 2 & 5.0 & 2 & 12.5 & 5 & 52.5 & 21 & 25.0 & 10 & $\mathrm{X} 9$ & \\
\hline 79.50 & 0.99 & 3.98 & 0.0 & 0 & 5.0 & 2 & 20.0 & 8 & 47.5 & 19 & 27.5 & 11 & $\mathrm{X} 10$ & \\
\hline \multirow[t]{2}{*}{77.70} & \multirow[t]{2}{*}{0.96} & 3.89 & & & & & & & & & & & المؤشر & \\
\hline & & & & & & & & & & & & & الكلي & \\
\hline & & & & يلية المناور & قيادة الات & المئوية ر المئ & كرارية والن & التوزيعان & & & & & & $\overline{3}$ \\
\hline نسبة الاستجابة & الانحراف & الوسط & & & & & & & & & & & المؤشر & $\overline{5}$ \\
\hline & المعياري & الحسابي & $\%$ & & $\%$ & & $\%$ & & $\%$ & & $\%$ & التكرار & & y \\
\hline 79.50 & 0.99 & 3.98 & 2.5 & 1 & 5.0 & 2 & 10.0 & 4 & 57.5 & 23 & 25.0 & 10 & X11 & \\
\hline 69.00 & 0.86 & 3.45 & 2.5 & 1 & 10.0 & 4 & 35.0 & 14 & 45.0 & 18 & 7.5 & 3 & X12 & \\
\hline 75.00 & 0.92 & 3.75 & 0.0 & 0 & 12.5 & 5 & 22.5 & 9 & 42.5 & 17 & 22.5 & 9 & X13 & $\overline{3}$ \\
\hline 72.50 & 0.89 & 3.63 & 0.0 & 0 & 10.0 & 4 & 27.5 & 11 & 52.5 & 21 & 10.0 & 4 & X14 & \\
\hline 69.50 & 0.86 & 3.48 & 5.0 & 2 & 15.0 & 6 & 22.5 & 9 & 42.5 & 17 & 15.0 & 6 & X15 & \\
\hline 73.10 & 0.90 & 3.66 & & & & & & & & & & & المؤشر & \\
\hline
\end{tabular}


المصدر : من إعداد الباحثين بالاعتماد على نتائج الحاسبة الالكترونية.

يلاحظظ مـن الجمدول (2) فيمـا يخص بعـد العضوية وجـود

نسبة اتفـاق ايجابية بين الأفراد المبحوثين قـدها (65.50\%)

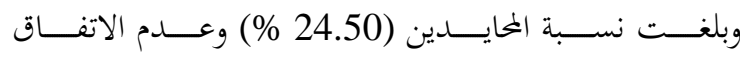
(10.00\%) والـذي جـاء بوسط حسـابي (3.70) وبـانخراف

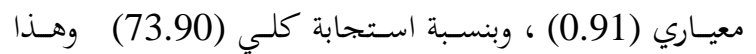

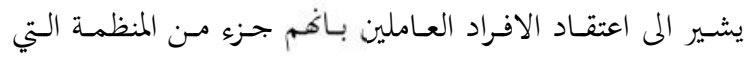
يعملون فيها ويسعون لتحقيق اهـدافها وتربطهم علاقة جيـدة

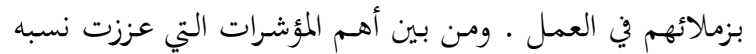

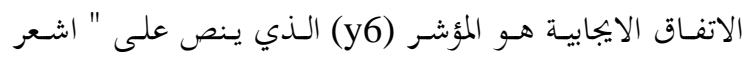

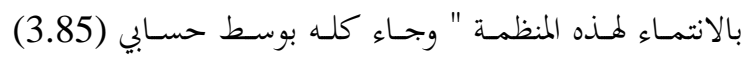
وبـانخراف معيساري (0.95)) ، وبنسـبة اسـتجابة (77.00) .

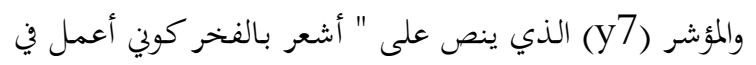

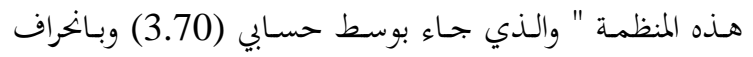
معياري (0.91) ، وبنسبة استجابة (74.00) ، والمؤشر (y9)

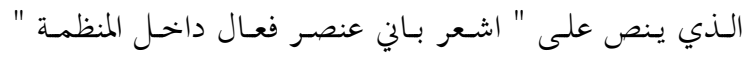
والذي جاء بوسط حسابي(3.68) وبانخراف معياري (0.90) ، وبنسبة استجابة (73.50).

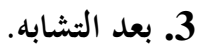

يلاحظظ مـن الجـدول (2) فيمـا يخـص بعـد التشـابه وجـود نسبة اتفـاق ايجابية بين الأفراد المبحوثين قـدرها (267.00\%)

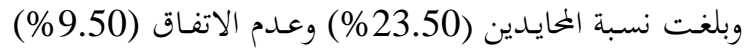

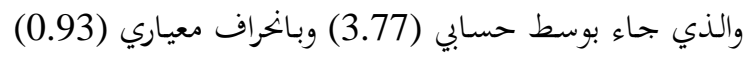

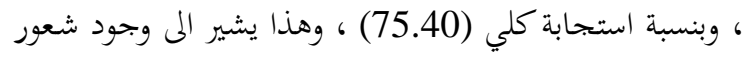

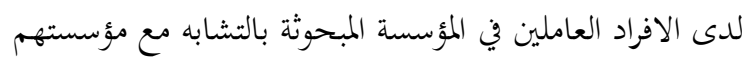

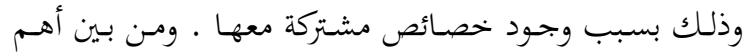
المؤشرات التي عززت نسبه الاتفاق الايجابية هو المؤشر (y15)

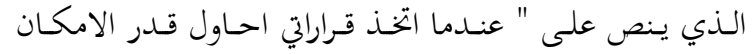
تجنيب تعريض المنظمة التي اعمل فيها للعواقب المحتملة التي تؤثر

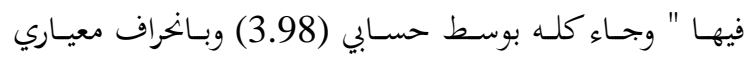

وبهـذا تظهـر نتـائح التحليـل الوصـفي لاجابـات الافـراد

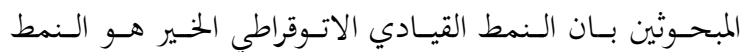
القيادي السائد في مديرية تربية زاخو لانه يمكن عن طريق ممارسة

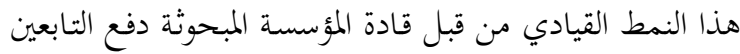

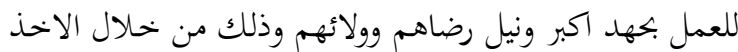
بارائهم ومناقشتهم ومشاركتهم في القرار المتخذ. 2.1.4 وصف متغير ابعاد التماثل التنظيمي.

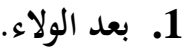

يلاحظ من الجحدول (2) فيما يخص بعد الولاء وجود نسبة

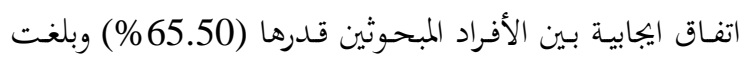

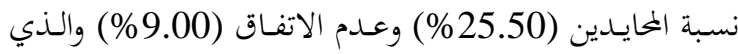
جـاء بوسـط حسـابي (3.71) وبــانحراف معيـاري (0.91)) ، وبنسبة استجابة كلي (74.20) ، وهـذا يـدل على ان الافراد العاملين يملكون شعور ايجابي تجـاه المنظمسة التي يعملـون فيها

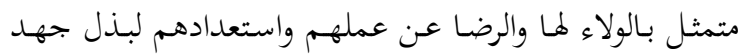

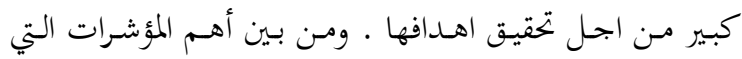

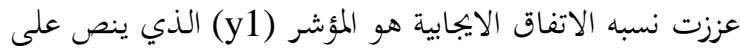

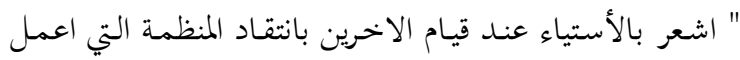
فيهـا " وجـاء كله بوسط حسـابي (3.88) وبـانخراف معيـاري

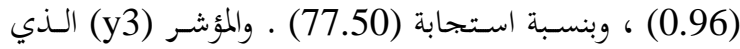
ينص على " المنظمة التي اعمل بها تستحق أخلاصي وولائي لها

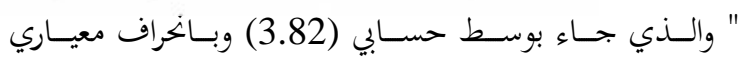

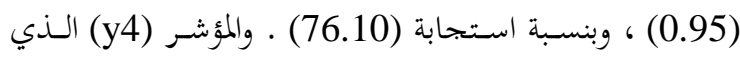
ينص على " انا مستعد دائما لبذل جهد كبير لمساعدة المنظمة

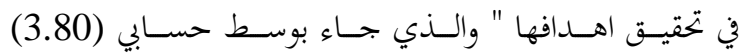
وبانحراف معياري (0.94) ، وبنسبة استجابة (76.00). 
الـذي يـنص على " اشعر بـأن أفراد المنظمـة يسعون (y12)

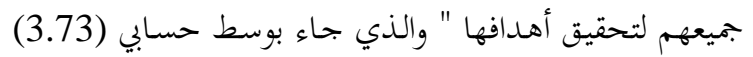

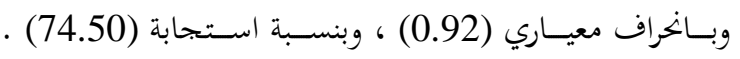

(0.99) ، وبنسبة استجابة (79.50) ـ والمؤشر (y11) الذي

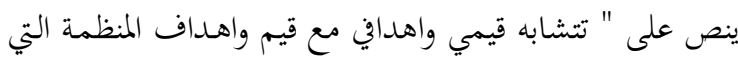

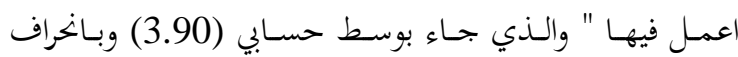

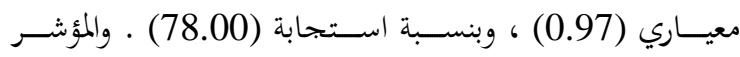

جدول (2): التكرارات والنسب المئوية والأوساط الحسابية والاخرافات المعيارية لابعاد التماثل التنظيمي

\begin{tabular}{|c|c|c|c|c|c|c|c|c|c|c|c|c|c|c|}
\hline \multicolumn{14}{|c|}{ التوزيعات النكرارية والنسب المئوية لبعد الولاء } & \\
\hline \multirow[t]{2}{*}{ ن الاستجابة } & \multirow{2}{*}{ الانحراف } & \multirow{2}{*}{ الحسابي } & \multicolumn{2}{|c|}{ ل الغق بشدة } & \multicolumn{2}{|c|}{ لا لا اتفق } & \multicolumn{2}{|c|}{ 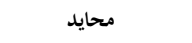 } & \multicolumn{2}{|c|}{ 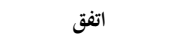 } & \multicolumn{2}{|c|}{ 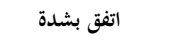 } & \multirow[t]{2}{*}{ 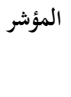 } & \\
\hline & & & $\%$ & 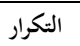 & $\%$ & 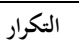 & $\%$ & 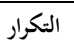 & $\%$ & 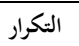 & $\%$ & 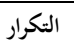 & & \\
\hline 77.50 & 0.96 & 3.88 & 0.0 & 0 & 2.5 & 1 & 27.5 & 11 & 50.0 & 20 & 20.0 & 8 & y1 & \\
\hline 68.50 & 0.85 & 3.43 & 2.5 & 1 & 15.0 & 6 & 35.0 & 14 & 32.5 & 13 & 15.0 & 6 & y2 & \\
\hline 76.10 & 0.95 & 3.82 & 2.5 & 1 & 2.5 & 1 & 22.5 & 9 & 57.5 & 23 & 15.0 & 6 & y3 & \\
\hline 76.00 & 0.94 & 3.80 & 5.0 & 2 & 2.5 & 1 & 17.5 & 7 & 57.5 & 23 & 17.5 & 7 & y4 & \\
\hline 73.00 & 0.90 & 3.65 & 0.0 & 0 & 12.5 & 5 & 25.0 & 10 & 47.5 & 19 & 15.0 & 6 & y5 & \\
\hline \multirow[t]{2}{*}{74.20} & \multirow[t]{2}{*}{0.91} & \multirow[t]{2}{*}{3.71} & \multicolumn{2}{|c|}{2.00} & \multicolumn{2}{|c|}{7.00} & \multicolumn{2}{|c|}{25.50} & \multicolumn{2}{|c|}{49.00} & \multicolumn{2}{|c|}{16.50} & 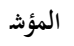 & \\
\hline & & & \multicolumn{4}{|c|}{9.00} & \multicolumn{2}{|c|}{25.50} & \multicolumn{4}{|c|}{65.50} & $\begin{array}{c}\text { الكلي } \\
\text { الكي }\end{array}$ & \\
\hline \multicolumn{14}{|c|}{ التوزيعات التكرارية والنسب المئوية لبعد العضوية } & $\overline{3}$ \\
\hline \multirow[t]{2}{*}{ 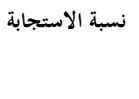 } & 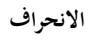 & 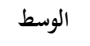 & \multicolumn{2}{|c|}{ ل الا اتفق بشدة } & \multicolumn{2}{|c|}{ لا اتفق } & \multicolumn{2}{|c|}{ 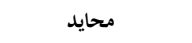 } & \multicolumn{2}{|c|}{ اتفق اتف } & \multicolumn{2}{|c|}{ 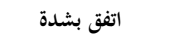 } & 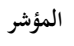 & \\
\hline & 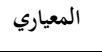 & 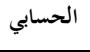 & $\%$ & التكرار & $\%$ & 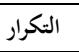 & $\%$ & 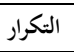 & $\%$ & 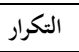 & $\%$ & 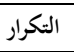 & & \\
\hline 77.00 & 0.95 & 3.85 & 2.5 & 1 & 2.5 & 1 & 20.0 & 8 & 57.5 & 23 & 17.5 & 7 & y6 & \\
\hline 74.00 & 0.91 & 3.70 & 2.5 & 1 & 10.0 & 4 & 27.5 & 11 & 35.0 & 14 & 25.0 & 10 & y7 & \\
\hline 72.50 & 0.89 & 3.63 & 5.0 & 2 & 5.0 & 2 & 30.0 & 12 & 42.5 & 17 & 17.5 & 7 & y8 & \\
\hline 73.50 & 0.90 & 3.68 & 7.5 & 3 & 5.0 & 2 & 17.5 & 7 & 52.5 & 21 & 17.5 & 7 & y9 & \\
\hline 72.50 & 0.89 & 3.63 & 2.5 & 1 & 7.5 & 3 & 27.5 & 11 & 50.0 & 20 & 12.5 & 5 & y10 & \\
\hline 73.90 & 0.91 & 3.70 & & & & & & & & & & & المؤشر & \\
\hline & & & & & & & & & & & & & & \\
\hline & & & & & وية لبعد ا & بلة والنسب & وزيعات الثا & & & & & & & $\overline{3}$ \\
\hline نسبة الاستجابة & الانحراف & الوسط & & & & & & & & & & & المؤشر & $\overline{3}$ \\
\hline & المعياري & الحسابي & $\%$ & النكرار & $\%$ & التكرار & $\%$ & النكرار & $\%$ & التكرار & $\%$ & النكرار & & \\
\hline 78.00 & 0.97 & 3.90 & 0.0 & 0 & 5.0 & 2 & 25.0 & 10 & 45.0 & 18 & 25.0 & 10 & y11 & \\
\hline 74.50 & 0.92 & 3.73 & 2.5 & 1 & 5.0 & 2 & 32.5 & 13 & 37.5 & 15 & 22.5 & 9 & y12 & \\
\hline 72.00 & 0.89 & 3.60 & 5.0 & 2 & 7.5 & 3 & 25.0 & 10 & 47.5 & 19 & 15.0 & 6 & y13 & \\
\hline 73.00 & 0.90 & 3.65 & 5.0 & 2 & 12.5 & 5 & 17.5 & 7 & 42.5 & 17 & 22.5 & 9 & y14 & \\
\hline 79.50 & 0.99 & 3.98 & 0.0 & 0 & 5.0 & 2 & 17.5 & 7 & 52.5 & 21 & 25.0 & 10 & y15 & \\
\hline
\end{tabular}


بحلة جامعة دهوك، المحلد: 22، العدد: 1 (العلوم الانسانية والاجتماعية)، ص 218-241 2019

https://doi.org/10.26682/hjuod.2019.22.1.11

75.40

$0.93 \quad 3.77$

2.50

7.00

23.50

23.50

45.00

67.00

22.00 المؤشر

9.50

المصدر : من إعداد الباحثين بالاعتماد على نتائج الحاسبة الالكترونية.

تــؤدي الى تعزيـز مســويات التماثـل التنظيمسي لــدى الافــراد

مالعان 2.4.عرض وتحليل علاقة الارتباط بين القيادة الاتوقراطية

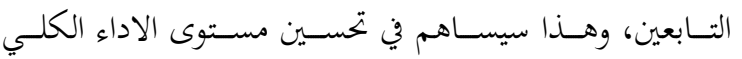

والتماثل التنظيمي.

للمنظمة ، وبهذا فإننا نرفض فرضية العدم وقبول الفرضية البديلة

يشير الجحدول (3) إلى وجود علاقة ارتباط معنوي بين القيادة

والـتي تــص علسى وجـود علاقـة ارتبـاط معنويسة بـين القيـادة

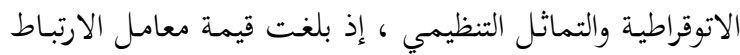

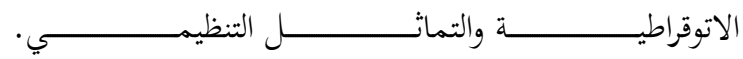

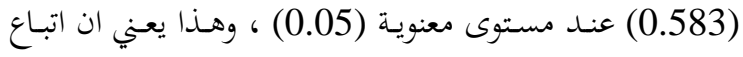

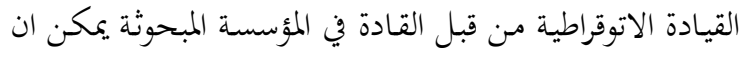

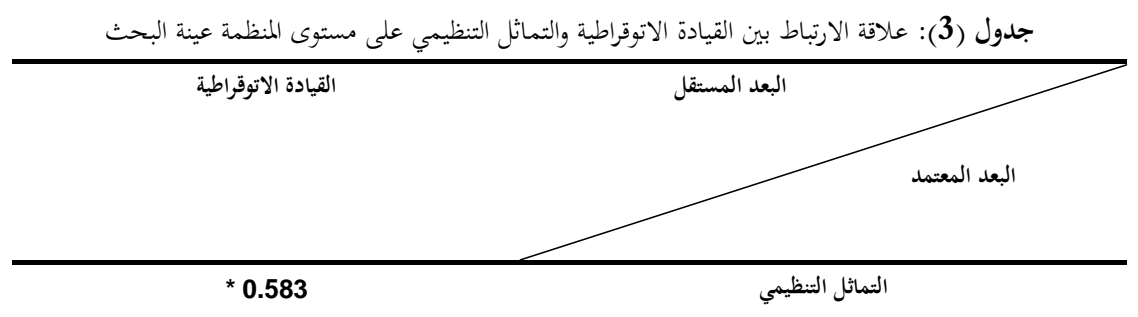

$* \mathbf{P} \leq \mathbf{0 . 0 5}$

$N=40$

المصدر : من إعداد الباحثين بالاعتماد على نتائج برنامج SPSS.

الافراد التابعين وحفزهم للعمل من اجل تحقيق اهداف المنظمة

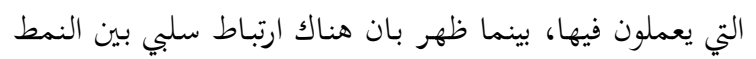

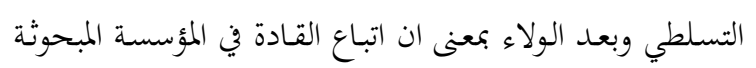
للنمط الاتوقراطي التسلطي سينتج عنه انخفاض ولاء التابعين

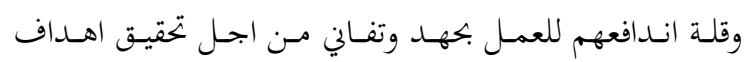

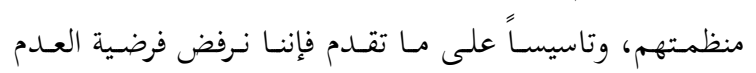

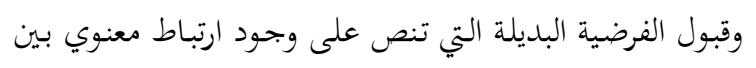

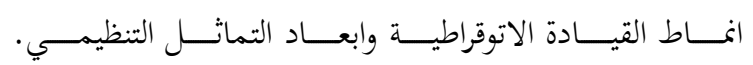

التمانل التطاقي علات الارتباط لكل نمط من انماط القيادة الاتوقراطية وابعاد التماثل التنظيمي على مستوى المتغيرات الفرعية. تركز هذه الفقرة على التحقق من صحة الفرضية الثانية والتي تنص على وجـود ارتبـاط معنوي بين انماط القيادة الاتوقراطية

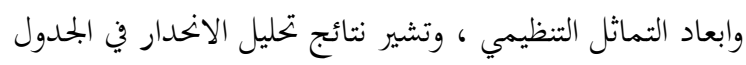

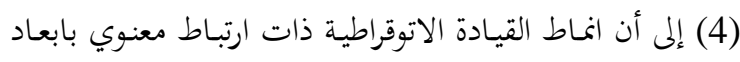
التماثل التنظيمي، وانخصر معامل هذه العلاقة بين ( 0.804 ،

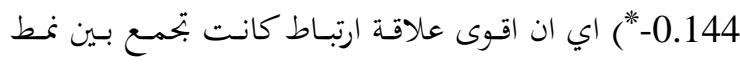

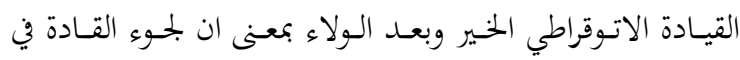

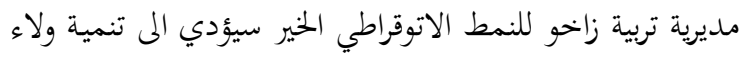

$$
\text { جدول (4): علاقات الارتباط بين انماط القيادة الاتوقراطية والتماثل التنظيمي على مستوى المتغيرات الفرعية }
$$


بحلة جامعة دهوك، المحلد: 22، العدد: 1 (العلوم الانسانية والاجتماعية)، ص 218-241 2019

https://doi.org/10.26682/hjuod.2019.22.1.11

\begin{tabular}{|c|c|c|c|c|}
\hline المناور & الخير & المتسلط & الدتغيرات الفرعية & البُعد المعتمد \\
\hline 0.119 & 0.804 & -0.144 & الولاء ل الو & ابعاد التماثل التنظيمي \\
\hline 0.243 & 0.408 & 0.213 & العضوية & \\
\hline 0.363 & 0.276 & 0.116 & 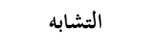 & \\
\hline
\end{tabular}

$* \overline{\mathbf{P} \leq 0.05}$

$\mathbf{N}=\mathbf{4 0}$

المصدر : من إعداد الباحثين بالاعتماد على نتائج برنامج SPSS.

(0.339) ، ويدعم ذلك قيمة معامل الانحدار (Beta) البالغة

4.4. عرض وتحليـل علاقة التأثير للقيـادة الاتوقراطيـة في

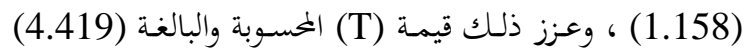

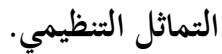

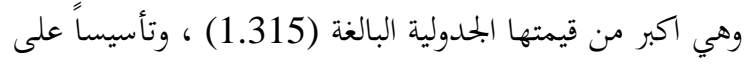

تشـير نتـائج تحليـل الانحـدار في الجــدول (5) إلى أن القيـادة

مـا تقدم فإننـا نرفض فرضية العـدم وقبول الفرضية البديلة التي

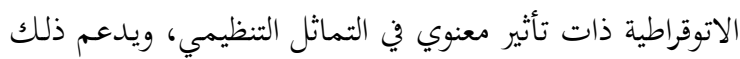

تنص على وجـود تأثير معنوي للقيـادة الاتوقراطية في التماثل

قيمـة (F) البالغـة (19.530) وهي اكسبر مسن قيمتها الجدوليـة

التنظيم

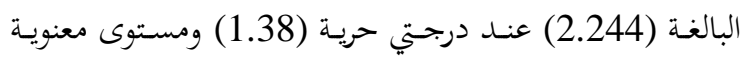

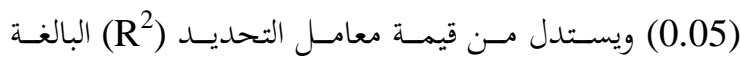

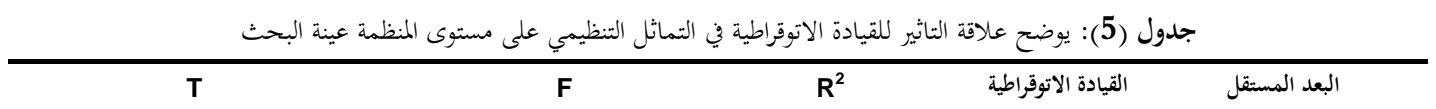

الجحسوبة

B1 Bo

البعد المعتمد

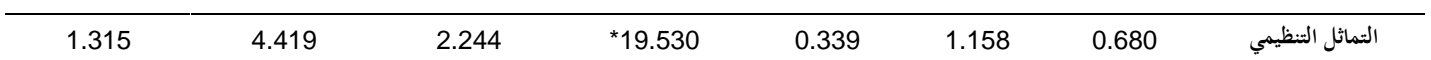

\begin{tabular}{|c|c|c|}
\hline${ }^{*} \mathbf{P} \leq \mathbf{0 . 0 5}$ & DF $(1,38)$ & $N=40$ \\
\hline
\end{tabular}

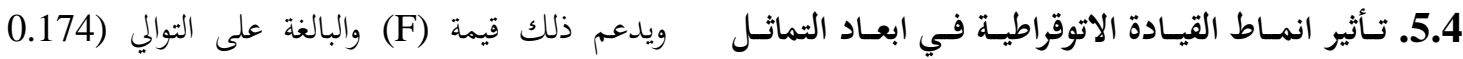

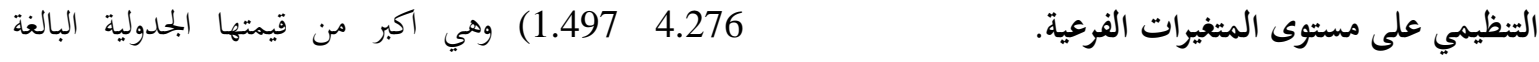
تشير نتائج تحليل الانحدار في الجدول (6) إلى أن لانماط (1.249) عند درجتي حرية (1.36) ومستوى معنوية (0.05)

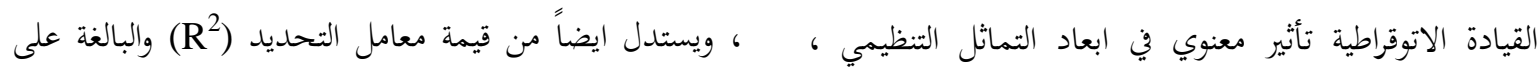


فرضية العدم وقبول الفرضية البديلة التي تنص على وجود تأثير معنوي لانماط القيادة الاتوقراطية في ابعاد التماثل التنظيمي.
التوالي (T)

المسوبة كما مبين في الجلدول ادناه وهي قيم اكبر من قيمتها

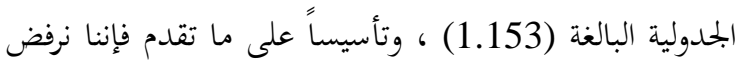

جدول (6): تأثير انماط القيادة الاتوقراطية في ابعاد التماثل التنظيمي على مستوى المتغيرات الفرعية للمنظمة المبحوثة

$\mathbf{F}$ $\mathbf{R}^{2}$ التماثل الننظيمي المتغير المعتمد

\begin{tabular}{|c|c|c|c|c|c|c|}
\hline الجدولية & المحسوبة & & B1 & Bo & & المتغير المستقل \\
\hline \multirow[t]{4}{*}{1.249} & 0.174 & 0.025 & 0.641 & 0.438 & المتسلط & \\
\hline & & & * $(4.451)$ & & & $\overline{3}$ \\
\hline & ${ }^{*} 4.276$ & 0.258 & $\begin{array}{c}0.702 \\
*(7.045)\end{array}$ & 0.587 & الخير & 高: \\
\hline & * 1.497 & 0.137 & $\begin{array}{c}0.804 \\
*(5.337)\end{array}$ & 0.618 & المناور & $\frac{2}{9}$ \\
\hline
\end{tabular}

DF $(1,36)$

المصدر : من إعداد الباحثين بالاعتماد على نتائج برنامج SPSS

2. يتضح من خلال البحث بأنه على الرغم من اتصاف القائد

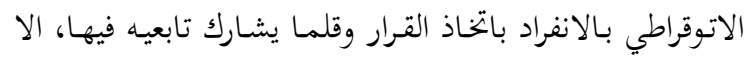

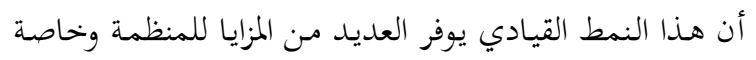
عندما تكون هناك حاجة لاتخاذ قرارات سريعة عندما يتطلب الأمر تولي مسؤولية الافراد وتوزيع المهام عليهم وتحديد المواعيد

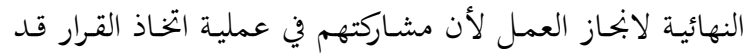
يؤدي الى تاخير العمل المراد انجازه.

3. أظهـرت نتـائح التحليـل الوصـفي بــأن الــمط القيـادي الاتوقراطي الخير هو النمط القيادي السائد في المؤسسة المبحوثة

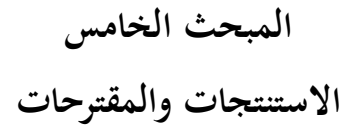

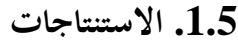
1. ان بلورة حالة من التماثل التنظيمي أصبحت ضرورة ملحة

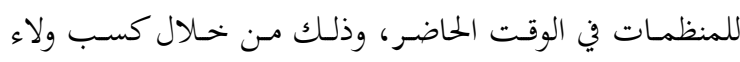
الأفراد العـاملين والعمـل على ادراكهـم لـدورهم واهميـة القيـام

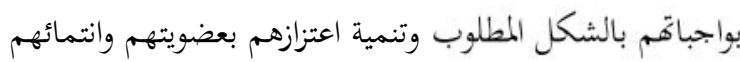
للمنظمة وبما يعزز من سمعة المنظمة ومكانتها. 
سيقود الى الخفاض ولاء ورضا الأفرد التابعين وتقليل اندفاعهم لأداء الاعمال المناطة اليهم.

9. بينت نتائح التحليل الاحصائي من خهلال اختبار الانماندار الخطي وجود تاثير معنوية لانماط القيادة الاتوقراطية في التماثل التنظيمي في المؤسسة المبحوثة، نستنتج من ذلك بان اتباع القادة

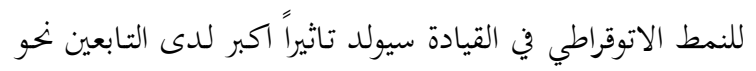
رفع حالة التماثل مع المنظمة التي يعملون فيها.

2.5 المقترحات 1. ضرورة السعي لتعزيز مستوى التماثل التنظيمي لدى موظفي

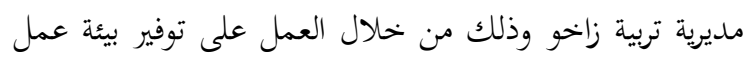

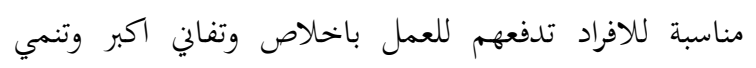
مستوى التزامهم بتحاه مؤسستهم وتزيد من مستويات ادائهم الوظيفي. 2. العمل المستمر على التعزيز من اتباع القادة الاداريين في المؤسسة المبحوثة للنمط القيادي الاتوقراطي الخير وذلك لأنه يعمل على تنمية ولاء الأفراد التابعين وشعورهم بالانتماء لمنظمتهم مما سينعكس ايجاباً في زيادة مستويات التماثل التنظيمي لديهم. 3. ضرورة قيام القادة الاداريين في المؤسسة المبحوثة وبشكل

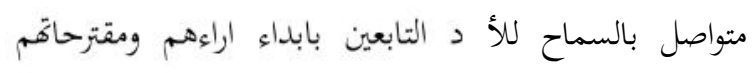

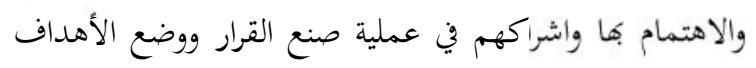

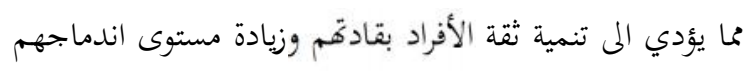

$$
\text { وتماثلهم مع المنظمة التي يعملون فيها. }
$$

4. أهمية قيام القادة الاداريين في المؤسسة المبحوثة بتوضيح رؤيتهم وايصاها لتابعيهم وذلك لكي يكون كل فرد على معرفة

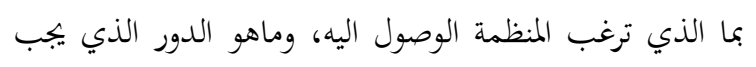
ان يقومو به لتحقيق ذلك الهدف.

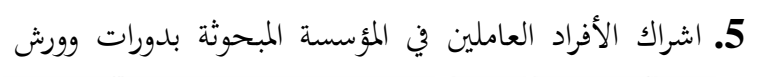
زيية لتعزيز خبراتم وتعليمهم مهارات جديدة في العمل وبما
اذ كان هناك اتفاق عام مرتفع من قبل الأفراد المبحوثين على

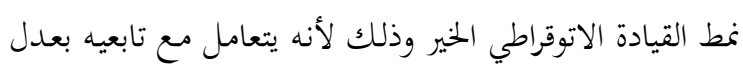
وانصاف ويتجنب استخدام التهديد والتلويح بالعقاب لهم.

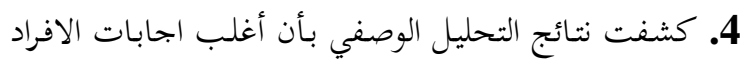
المبحوثين كانت متذبذبة بين الاتفاق والحياد حول نمط القيادة

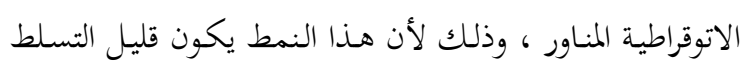

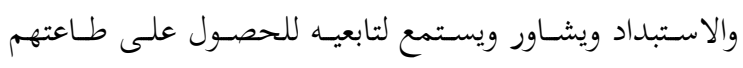
وولائهم. 5. كشـفت نتـائج التحليـل الوصـفي بـان اجابـات الأفـراد

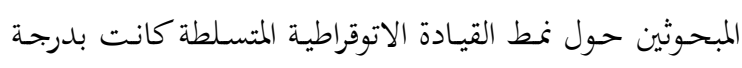

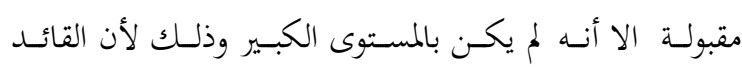

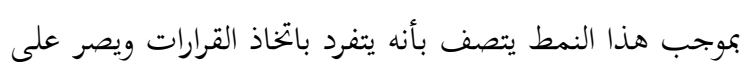
اذعان التابعين لأوامره. 6. كشفت نتائج التحليـل الوصفي بـأن هنـاك اتفـاق بدرجـة

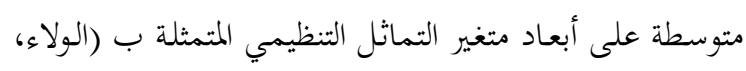

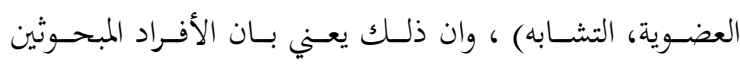
يشعرون بولاء بتحاه المنظمة التي يعملون فيها ويشعرون بالاعتزاز

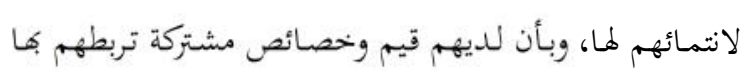

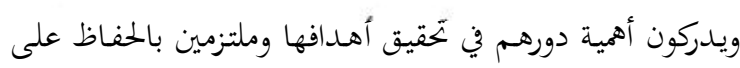
سمعتها وبنحاحها. 7. أشارت نتائج التحليل الاحصائي وجود علاقة ارتباط ايجابية

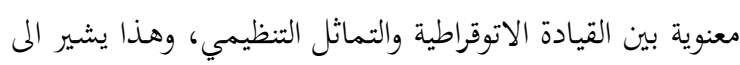

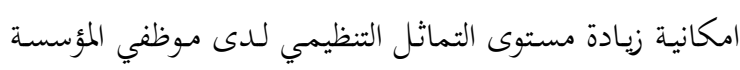

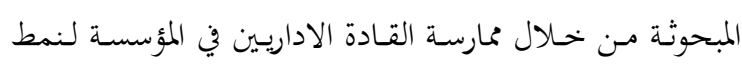
القيادة الاتوقراطية. 8. أظهرت نتائج التحليل الاحصائي الى وجود ارتباط معنوي موجب بين كل نمط من انماط القيادة الاتوقراطية وأبعاد التماثل

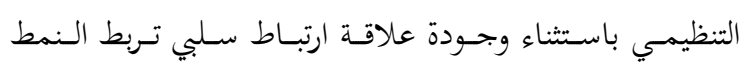
القيادي الاتوقراطي المتسلط وبعد الولاء، نستنتج من ذلك بلك بان

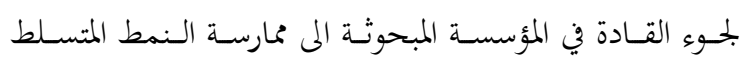




\section{ب- الدوريات والمجلات العلمية:}

6- البشابشة، سامر عبد ابخيد، (2008)، أثر العدالة التنظيمية في بلورة

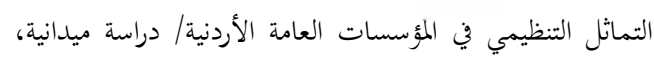

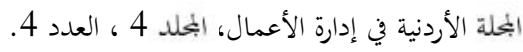
7- الخليفات, مها عبد العزيز، (2006)، أثر ممارسة المهارات القيادية

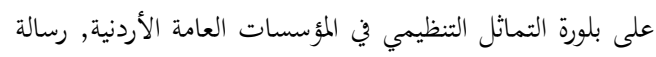
ماجستير, قسم الأدارة العامة, جامعة مؤتة.

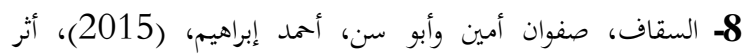

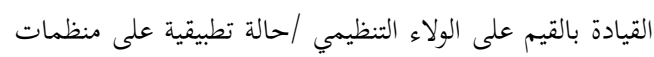

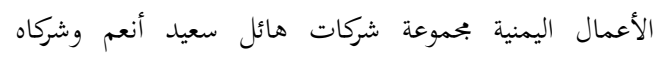
أنموذجا، جامعة السودان للعلوم والتكنولوجيا - كلية الدراسات التمات

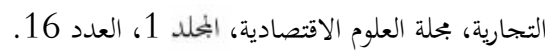

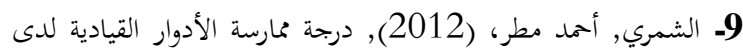
عمداء الكليات في جامعة الكويت وعلاقتها بالتماثل التنظيمي لدى أعضاء هيئة التدريس من وجهة نظرهم, رسالة ماجستير، كلية العلوم التربوية, جامعة الشرق الأوسط, الاردن. 10- الشواورة، طه سالم، (2016)، أثر التماثل التنظيمي في دافعية العمل لدى معلمي وزارة التربية والتعليم الأردنية في مديرية التربية والتعليم لقصبة الكرك، بملة الجامعة الإسلامية للدراسات الاقتصادية والإدارية، البحلد 24، العدد 1. 11- الصرايرة، خالد أحمد، (2009)، التماثل التنظيمي لأعضاء الهيئات

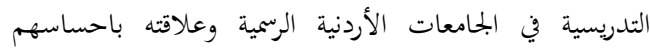

بالأمن، قسطنطينية، الجزائر، بحلة منتدى الاستاذ، العدد العدات 5.

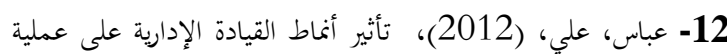

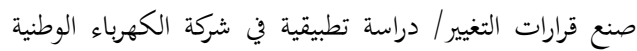

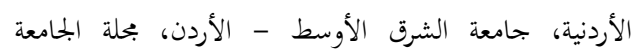
الإسلامية للدراسات الاقتصادية والإدارية، البحلد 20، الإدئة، العدد 1.

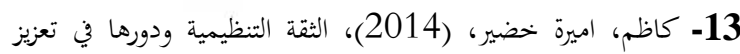
الولاء التنظيمي دراسة تطبيقية لعدد من العاملين في فروع مصرف الرافدين في محافظة النجف الأشرف، بحلة الغربي للعلوم الادارية

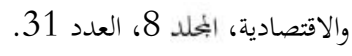

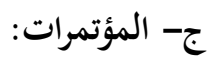
14- النعيمي، محمد عبد العال وبخم، نجم عبود، (2012)، الذكاء

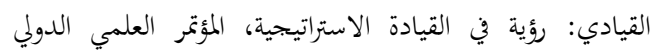

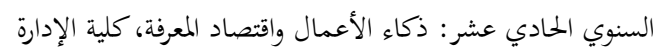
والإقتصاد، جامعة الزيتونة، عمان، الاردن.
يزيد من شعورهم بالمسؤولية ويعزز من مستوى تماثلهم مع

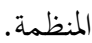

6. ضرورة التعرف على حاجات ورغبات الأفراد التابعين

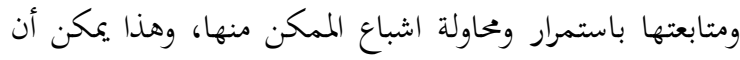

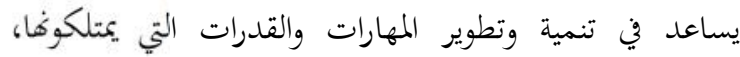
وبالتالي امكانية أن يؤثر ذلك في تعزيز مستوى التماثل التنظيمي لديهم.

قائمة المصادر أولا. المصادر باللغة العربية: أ- الرسائل والأطاريح الجامعية:

1- صالح، خالد مهدي، (2014)، تأثير الصراع البناء في التماثل التنظيمي/ بحث تطبيقي في وزارة التخطيط العراقية، رسالة

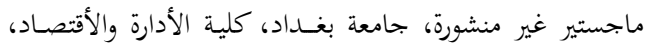
قسم الأدارة العامـة، بغداد، العراق. 2- طوالبة، توفيق حامد، (2008)، أثر الأنماط القيادية على إدارة الصراع التنظيمي لدى المديرين/ دراسة ميدانية على المؤسسات العامة في الأردن، اطروحة دكتوراه فلسفة، الاكاديمية العربية للعلوم

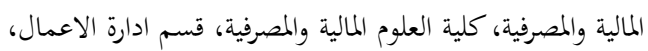

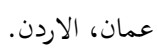
3- كشمولة، عمر محمد صبحي عبد الرزاق، (2007)، تأثير النمط القيادي في بناء القدرات الاستراتيجية للمنظمة/ دراسة تحليلية

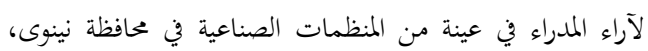
رسالة ماجستير غير منشورة، جامعة الموصل، كلية الإدارة والاقتصاد، قسم ادارة الاعمال، موصل، العراق.

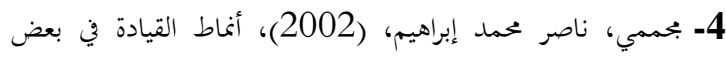
المؤسسات الصناعية الخاصة وعلاقاتحا بالنمو المهني لدى العاملين

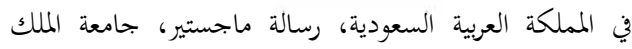

$$
\text { سعود، كلية التربية، قسم علم النفس، الرياض، السعودية. }
$$
5- النزاري، هاشم علي احمد، (2016)، المهارات الناعمة للقيادة ودورها

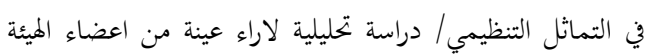
التدريسية في الجامعات الحكومية - محافظة دهوك، رسالة

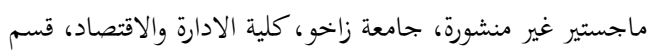
ادارة الاعمال، زاخو، اقليم كردستان-العراق. 
3- Çeri-Booms, Meltem, (2012), How Can Authentic Leaders Create Organizational Identification ? An Empirical Study On Turkish Employees, International Journal of Leadership Studies, Vol. 7, No. 2.

4- Khan, Muhammad Saqib \& Khan, Irfanullah \& Qureshi, Qamar Afaq, (2015), The Styles of Leadership: A Critical Review, Journal of Public Policy and Administration Research, Vol. 5 , No. 3.

5- Milton, L. \& Westphal, J. , (2005), Identity Confirmation Networks and Cooperation in work group, Academy of management gournal, Vol. 38, No. 2.

6- Pandey, Chetna \& Khare, Rajni, (2012), Impact of Job Satisfaction and Organizational Commitment on Employee Loyality, International Journal of Social Science \& Interdisciplinary Research ,Vol.1, Issue 8.

7- Philip, Usman Akor, (2014), Influence of Autocratic Leadership Style on the Job Performance of Academic Librarians in Benue State, Department of Library and Information Technology Federal University of Technology, Minna, Nigeria, Vol. 4, No. 7.

8- Van, Knippenberg D. \& Sleebos, E. (2006). Organizational Identification versus Organizational Commitment: Self-definitions, Social exchange, and Job Attitudes, Journal of B-Books: Organizational Behavior, Vol. 2, No.4.

9- Daft, Richard L., (2006), The New Era Of Management, Thomson-Western South Publishing, Ohio USA.

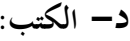

$$
\begin{aligned}
& \text { 15- أبو بكر, مصطفى, (2003)، المدير المعاصر وإدارة الأعمال في } \\
& \text { بيئة العولمة المعاصرة, الدار الجامعية، الإسكندرية، مصر. }
\end{aligned}
$$

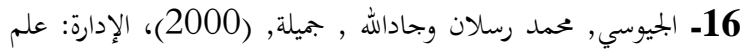

$$
\begin{aligned}
& \text { وتطبيق, الطبعة الأولى, دار المسيرة للنشر والتوزيع, عمان, }
\end{aligned}
$$

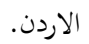

$$
\begin{aligned}
& \text { 17- العتبي، صبحي جبر، (2005)، تطور الفكر والاسايب في } \\
& \text { الإدارة، ط1، دار حامد للنشر والتوزيع، عمان، الاردن. }
\end{aligned}
$$

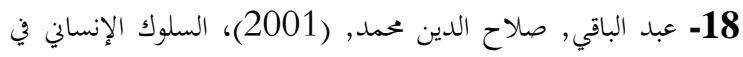

$$
\begin{aligned}
& \text { المنظمات, الدار الجامعية, الإسكندرية، مصر. }
\end{aligned}
$$

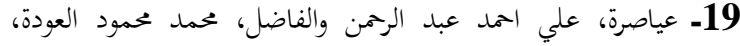

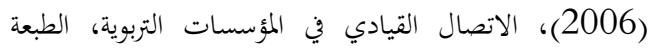

$$
\begin{aligned}
& \text { الاولى، دار حامد للنشر والتوزيع، عمان، الاردن. }
\end{aligned}
$$

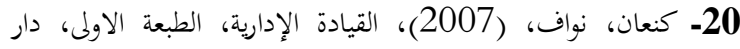

$$
\begin{aligned}
& \text { الثقافة للنشر والتوزيع، عمان، الاردن. } \\
& \text { ثانياًَ- المصادر باللغة الأجنبية: }
\end{aligned}
$$

\section{A-Journals \& Periodical}

1- Ashforth, E.B. \& Harrison, H.S. \& Corey, G.K., (2008), Identification in Organization: An Examination of Four Fundamental Questions, Journal Management, Vol. 34, No. 3.

2- Bamber, E. M., \& Iyer, V. M. (2002), Big 5 auditors, professional and organizational identification: Consistency or conflict? Auditing: A Journal of Practice \& Theory, Vol. 21, No. 2.

\title{
THE ROLE OF AUTOCRATIC LEADERSHIP PATTERNS IN ENHANCING ORGANIZATIONAL SYMMETRY \\ "A EXPLORATORY STUDY OF THE VIEWS OF A SAMPLE OF MEMBERS MEMBERS OF DIRECTORATE OF EDUCATION ZAKHO "
}

\author{
Ali Abdullatef Abdullah, Rush Ibrahim Mohammed and Mohammed Abdulrahman Omar \\ Dept. Administration Sciences, College of Administration \& Economic-University of Zakho
}

\section{ABSTRACT}

The research aims to determine the role of autocratic leadership patterns in organizational symmetry among the members of Directorate of Education Zakho. The research presented a theoretical framework dealing with the variables of autocratic leadership, organizational symmetry, and practical framework in order to identify the nature of the correlation between the 
patterns of autocratic leadership as an independent variable and organizational symmetry as a dependent variable. This has been tested by the use of a set of analytical statistical methods such as arithmetical averages, standard deviations, Pearson correlation coefficient, linear regression coefficient, $T$ test, $F$ test. The researchers reached a number of conclusions, the most prominent of which: There is a significant correlation and effect between the autocratic leadership and the organizational symmetry, This indicates that the possibility of increasing the level of organizational symmetry among the members through the practice of the administrative leaders in the investigated institution of the style of autocratic leadership. One of the most important proposals of the research: the continuous work to strengthen following of the administrative leaders in the investigated institution for the leadership style of Benevolent autocratic, because it works to develop the loyalty of subordinates and their sense of belonging to their organization, which will reflect positively in increasing levels of organizational symmetry.

يوخته

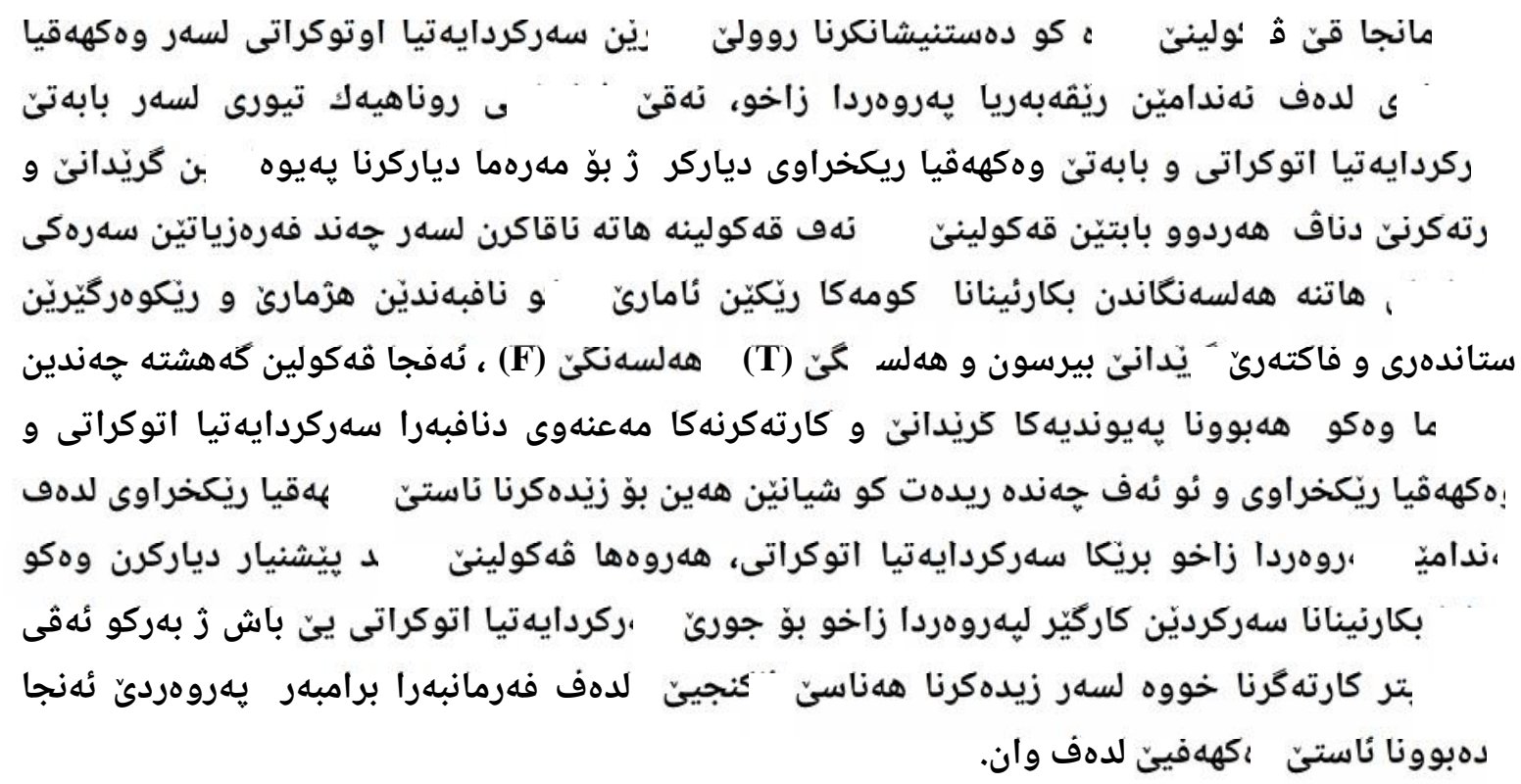


(1) الملحق

$$
\text { كلية الإدارة والاقتصاد زاخو }
$$

م/استمارة استبانة

السلام عليكم ورمة الله وبركاته. تحية طيبة.......

نضع بين أيديكم استبانة بعنوان " دور انماط القيادة الاتوقراطية في تعزيز مستوى التماثل التنظيمي/ دراسة استطلاعية لاراء عينة من موظفي مديرية تربية زاخو " ، وتمثل هذه الاستبانة جزءا من متطلبات مشروع بحث. وتعد مشاركتكم في تقديم المعلومات الكافية والمطلوبة بدقة

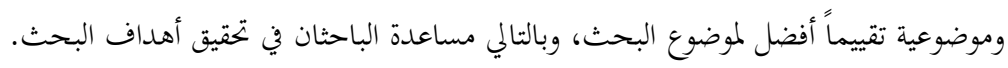

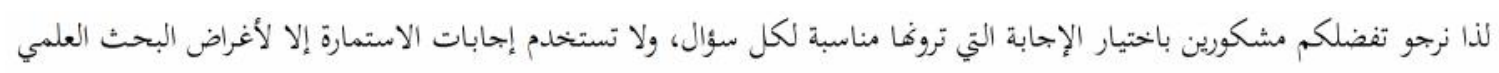

\section{شاكرين تعاونكم معنا}

$$
\text { فقط، ولا داعي لذكر الاسم. }
$$

$$
\text { الباحثون }
$$

$$
\begin{aligned}
& \text { أولاً:-- معلومات عامة } \\
& \text { الرجاء وضع إشارة ( ل ل) في البديل المناسب لكل عبارة من العبارات التالية : } \\
& \text { أنثى } \square
\end{aligned}
$$




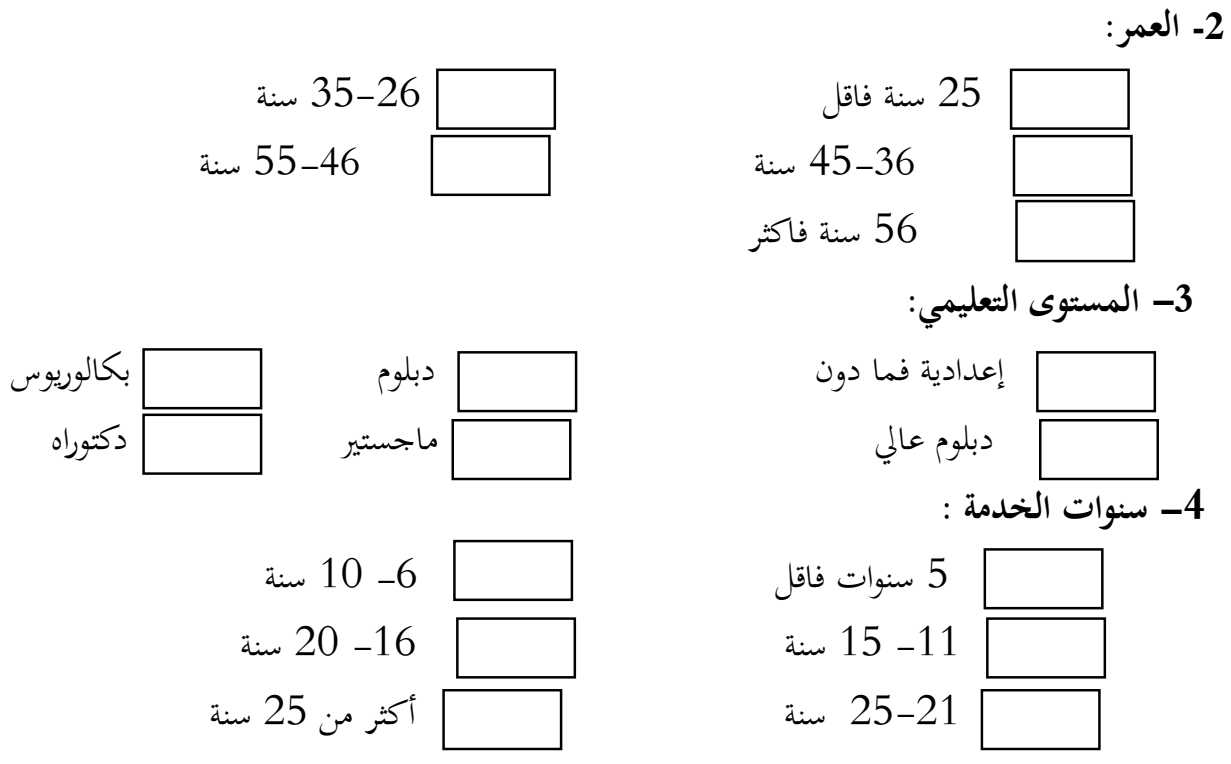

ثانيا: انماط القيادة الاتوقراطية.

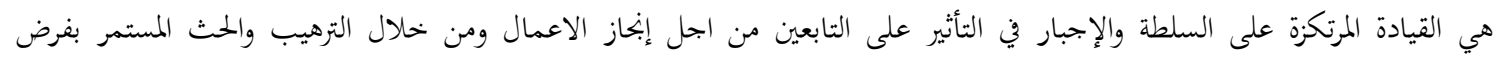

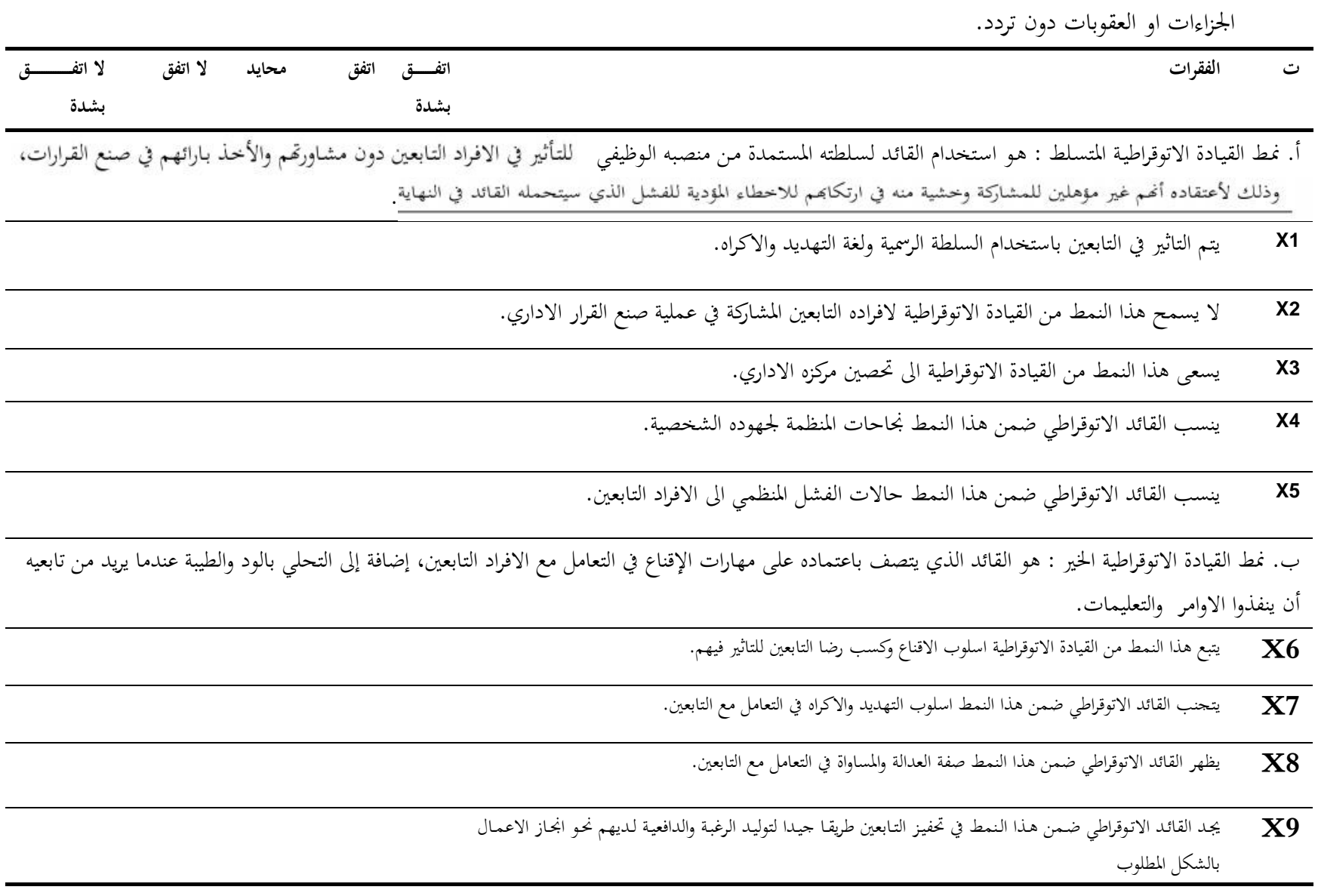




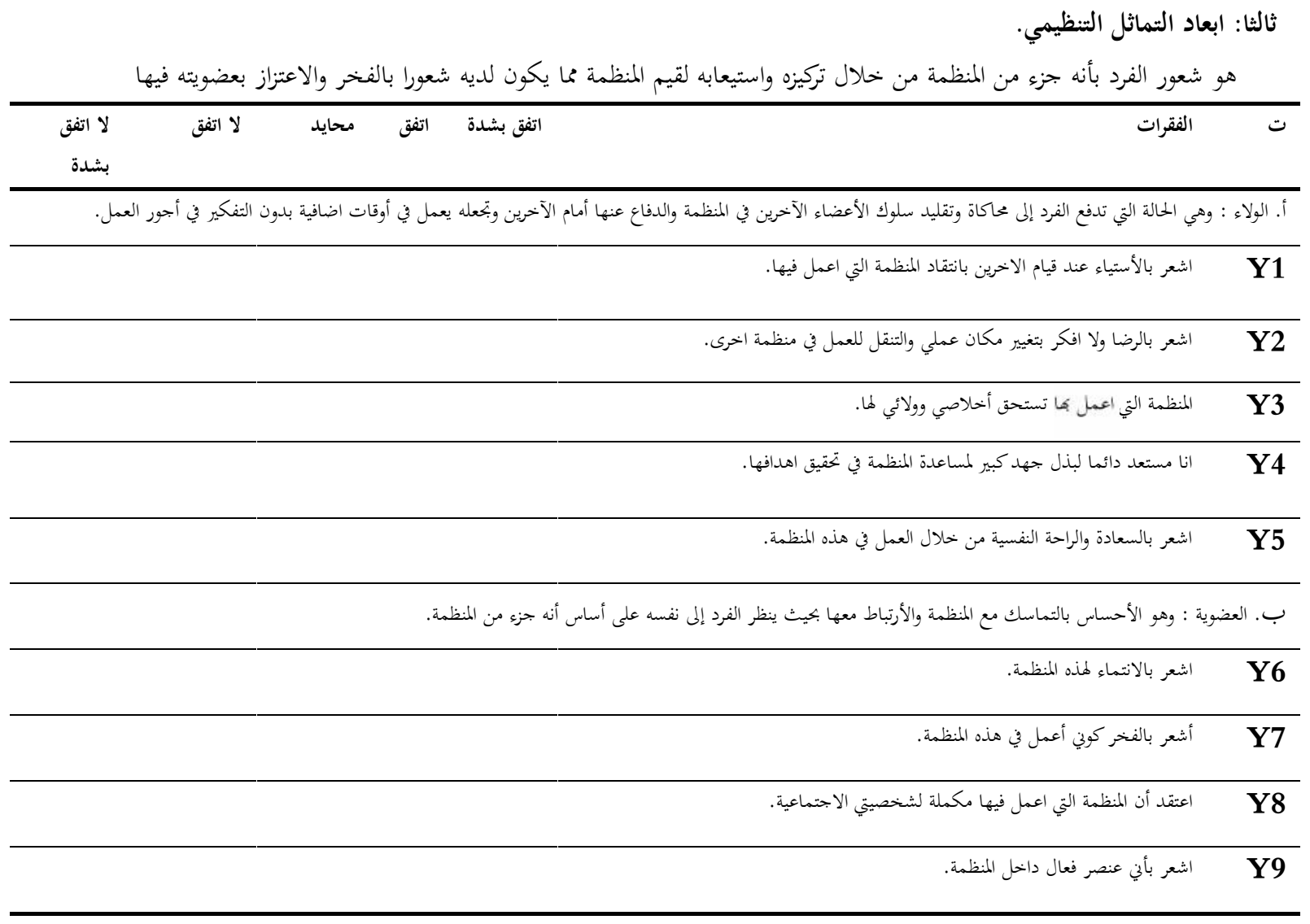


